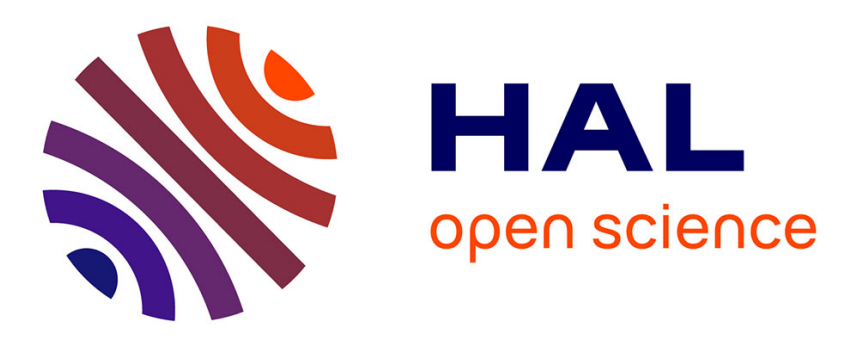

\title{
Synthesis and characterization of thorium-bearing britholites
}

\author{
O. Terra, F. Audubert, N. Dacheux, C. Guy, Renaud Podor
}

\section{To cite this version:}

O. Terra, F. Audubert, N. Dacheux, C. Guy, Renaud Podor. Synthesis and characterization of thorium-bearing britholites. Journal of Nuclear Materials, 2006, 354, pp.49-65. 10.1016/j.jnucmat.2006.02.094 . in2p3-00119645

\section{HAL Id: in2p3-00119645 https://hal.in2p3.fr/in2p3-00119645}

Submitted on 20 Dec 2006

HAL is a multi-disciplinary open access archive for the deposit and dissemination of scientific research documents, whether they are published or not. The documents may come from teaching and research institutions in France or abroad, or from public or private research centers.
L'archive ouverte pluridisciplinaire HAL, est destinée au dépôt et à la diffusion de documents scientifiques de niveau recherche, publiés ou non, émanant des établissements d'enseignement et de recherche français ou étrangers, des laboratoires publics ou privés. 


\section{Synthesis and characterization of thorium-bearing britholites}

Olivier Terra $^{\mathrm{a}}$, Fabienne Audubert ${ }^{\mathrm{b}}$, Nicolas Dacheux $^{\mathrm{a}}{ }^{\mathrm{*}}$, Christophe Guy $^{\mathrm{c}}$ and Renaud Podor ${ }^{\mathrm{d}}$

a Groupe de Radiochimie, IPNO, Bât. 100, Université Paris-Sud-11, 91406 Orsay, France

${ }^{\mathrm{b}}$ CEA Cadarache, DEN/DEC/SPUA/LTEC, Bât. 307, 13108 Saint Paul Lez Durance, France

${ }^{\mathrm{c}}$ CEA Cadarache, DEN/DEC/SA3C/LARC, Bât. 152, 13108 Saint Paul Lez Durance, France

${ }^{\mathrm{d}}$ LCSM (CNRS UMR 7555) Université H. Poincaré-Nancy I, BP 239, 54506 Vandouvre lès Nancy, France

* Corresponding author: DACHEUX Nicolas

Groupe de Radiochimie

Institut de Physique Nucléaire d'Orsay

Université de Paris-Sud-11, Bât. 100

91406 Orsay, France.

Phone: $\quad+33-169157346$

Fax : $\quad+33-169157150$

E-mail :dacheux@ipno.in2p3.fr 


\begin{abstract}
In the field of the immobilization of tri- and tetravalent minor actinides, apatites and especially britholites were already proposed as good candidates. In order to simulate tetravalent minor actinides, the incorporation of thorium, through dry chemical routes, was studied in britholite samples of general formula $\mathrm{Ca}_{9} \mathrm{Nd}_{1-x} \mathrm{Th}_{x}\left(\mathrm{PO}_{4}\right)_{5-x}\left(\mathrm{SiO}_{4}\right)_{1+x} \mathrm{~F}_{2}$. The study showed that the incorporation of thorium was effective whatever the thorium reagent used or the grinding conditions considered. Nevertheless, it appeared necessary to use mechanical grinding ( $30 \mathrm{~Hz}, 15$ minutes) before heating treatment $\left(T=1400^{\circ} \mathrm{C}, 6\right.$ hours) to improve the reactivity of powders and the sample homogeneity. In these conditions, the incorporation of thorium in the britholite structure occurred above $1100^{\circ} \mathrm{C}$. The heating treatment at $1400^{\circ} \mathrm{C}$ led to single phase and homogeneous compounds. This work also underlined the necessity to prefer the coupled substitution $\left(\mathrm{Nd}^{3+}, \mathrm{PO}_{4}{ }^{3-}\right) \Leftrightarrow\left(\mathrm{Th}^{4+}, \mathrm{SiO}_{4}{ }^{4-}\right)$ instead of $\left(\mathrm{Nd}^{3+}, \mathrm{F}^{-}\right) \Leftrightarrow\left(\mathrm{Th}^{4+}\right.$, $\mathrm{O}^{2-}$ ), in order to prepare pure and single phase samples in all the range of composition examined.
\end{abstract}




\section{Introduction}

In the frame of long-term storage of nuclear wastes, several ceramic matrices were already proposed as good candidates for the immobilization of minor actinides such as $\mathrm{Np}$, Am or $\mathrm{Cm}$ [1]. Zirconolite $\mathrm{Ca}_{1-x} \mathrm{Nd}_{x} \mathrm{ZrTi}_{2-x} \mathrm{Al}_{x} \mathrm{O}_{7}$, solid solutions monazite/brabantite $\mathrm{Ln}_{1-2 x}^{\mathrm{III}} \mathrm{Ca}_{x} \mathrm{An}_{x}^{\mathrm{IV}} \mathrm{PO}_{4}$, Thorium Phosphate-Diphosphate $(\beta-\mathrm{TPD})$, associated solid solutions $\beta-\mathrm{Th}_{4-x} \mathrm{An}_{x}^{\mathrm{IV}}\left(\mathrm{PO}_{4}\right)_{4} \mathrm{P}_{2} \mathrm{O}_{7}$ and $\beta$-TPD/monazite composites and finally apatites (with general formula $\mathrm{Me}_{10}\left(\mathrm{XO}_{4}\right)_{6} \mathrm{Y}_{2}$ with $\mathrm{Me}=\mathrm{Ca}^{2+}, \mathrm{Ln}^{3+}, \mathrm{An}^{3+}$ or $\mathrm{An}^{4+}, \mathrm{X}=\mathrm{Si}$ or $\mathrm{P}$ and $\mathrm{Y}=\mathrm{F}$ or $\mathrm{O}$ ) were considered for the simultaneous incorporation of $\mathrm{An}(\mathrm{III})$ and $\mathrm{An}(\mathrm{IV})$ [2]. Indeed, in natural apatites, particularly those coming from the Oklo fossil nuclear reactors (Gabon), the structure was able to immobilize over the lanthanides, a large variety of cationic substitution (as example by $\mathrm{U}, \mathrm{Th}, \mathrm{Pu}$ ) [3,4]. Silicate based apatite samples (britholites) of In Ouzzal site (Algeria) contain up to $50 \mathrm{wt} . \%$ of trivalent lanthanides ( $\mathrm{La}, \mathrm{Ce}, \mathrm{Nd}$ ) and tetravalent actinides (U, Th) [5]. Moreover, the apatitic structure seems to be able to anneal the defects generated by self-irradiation, even at low temperature [6]. But it has been also proved that the metamictization (destruction of the crystal lattice consequently to radiation damage) depends on the chemical composition of the apatites [6].

The formation of $\mathrm{Ce}$ (III)-bearing apatite was observed in natural media. So, the preparation of full-silicated apatites bearing large amounts of Ce (up to 10 atoms per unit formula in the calcium sites) has been reported [7-11]. The chemical compositions were determined from the substitution of $\mathrm{Ce}^{3+}$ in the $\mathrm{Ca}^{2+}$ site. More recently, in some natural apatites, the cerium was found to be tetravalent depending on the oxidizing conditions considered but not homogeneously distributed in the structure [12,13]. Although a lot of natural Th-bearing apatites were considered for the Th-U thermochronology [14-16], no study 
was published on synthetic Th-apatites except the preparation of the full-silicated apatite $\mathrm{Ca}_{6} \mathrm{Th}_{4}\left(\mathrm{SiO}_{4}\right)_{6} \mathrm{O}_{2}$ reported by Engel [17].

Only few papers were dedicated to the incorporation of uranium in britholites. Among them, that published by El Ouerzenfi et al. reported the incorporation of uranium at a limit of 0.48 atom per formula in britholite with general composition $\mathrm{Ca}_{5} \mathrm{La}_{5}\left(\mathrm{PO}_{4}\right)_{3}\left(\mathrm{SiO}_{4}\right)_{3} \mathrm{O}_{2}$ [18]. The authors showed that for upper values the excess of uranium was present in the oxide form $\mathrm{UO}_{2}$ and/or $\mathrm{U}_{3} \mathrm{O}_{8}$. Vance et al. reported the preparation of full-silicated apatite with formula $\mathrm{Ca}_{2} \mathrm{Gd}_{7} \mathrm{U}_{0.33}\left(\mathrm{SiO}_{4}\right)_{6} \mathrm{O}_{2}$ after calcination under inert or in reducing atmosphere [19].

The incorporation of $\mathrm{Pu}(\mathrm{IV})$ was recently obtained in a full-silicated apatite, leading to the formation of $\mathrm{Ca}_{2.1} \mathrm{Gd}_{7.3} \mathrm{Pu}_{0.6}\left(\mathrm{SiO}_{4}\right)_{6} \mathrm{O}_{2}$. Under reducing conditions, $\mathrm{Pu}(\mathrm{III})$ was incorporated in $\mathrm{Ca}_{2} \mathrm{Pu}_{8}\left(\mathrm{SiO}_{4}\right)_{6} \mathrm{O}_{2}[19]$.

In the aim to study Cm-doped nuclear waste glasses, crystallites of $\mathrm{Ca}_{3}(\mathrm{Gd}, \mathrm{Cm})_{7}\left(\mathrm{SiO}_{4}\right)_{5}\left(\mathrm{PO}_{4}\right) \mathrm{O}_{2}$ were systematically prepared [20]. An extensive study of single phase ${ }^{244} \mathrm{Cm}$-doped $\mathrm{Ca}_{2} \mathrm{Nd}_{8}\left(\mathrm{SiO}_{4}\right)_{6} \mathrm{O}_{2}$ was carried out to understand the self-radiation damage from $\alpha$-decay [21,22]. In these samples, 2.3 mol. $\%$ of $\mathrm{Cm}_{2} \mathrm{O}_{3}$ (containing $62 \%$ of ${ }^{244} \mathrm{Cm}, \mathrm{T}_{1 / 2}$ = 19 years) was substituted to $\mathrm{Nd}_{2} \mathrm{O}_{3}$. No information was given on the structural insertion of actinides issued from the $\alpha$-decay of ${ }^{244} \mathrm{Cm}$. These radiation damages induced the transformation of the crystallized apatite to amorphous solid. But, geochemical observations on natural apatites showed that silicated apatites are always found in the metamict state although the mono-silicated fluorapatite is always found to be crystallized despite they received thermal events and severe irradiation environment [6]. For this reason, the monosilicated britholite $\mathrm{Ca}_{9} \mathrm{Nd}\left(\mathrm{PO}_{4}\right)_{5}\left(\mathrm{SiO}_{4}\right) \mathrm{F}_{2}$ (in which $\mathrm{Nd}$ is used as a surrogate of trivalent actinides) was first considered in the aim to immobilize actinides [23].

On the basis of the natural analogues and external irradiation studies [24] which clearly identified the mono-silicated fluorapatite as a potential host matrix and on the basis of the 
synthesis [23,25] and the sintering [26,27] studies developed on Nd-bearing britholites, the incorporation of tetravalent actinides (Th, U) in britholites was examined.

The limit of incorporation was first fixed to $10 \mathrm{wt} . \%$. Neodymium was used as a surrogate of trivalent actinide. In order to perform the incorporation of tetravalent actinides, neodymium was partly substituted by thorium in the aim to prepare $\mathrm{Ca}_{9} \mathrm{Nd}_{0.5} \mathrm{Th}_{0.5}\left(\mathrm{PO}_{4}\right)_{4.5}\left(\mathrm{SiO}_{4}\right)_{1.5} \mathrm{~F}_{2} \quad$ samples. $\quad$ So, $\quad(\mathrm{Nd}, \mathrm{Th})$-britholites were synthesized considering several ways, all based on dry chemical processes. We mainly focused our study on the use of thorium oxide as a Th-reagent in order to evidence the successive steps of the incorporation of this actinide in the britholite structure. Finally, the influence of the nature of the coupled substitution considered on the thorium incorporation in the britholite structure was also examined.

In order to simplify the notation, britholites loaded with neodymium (e.g. $\left.\mathrm{Ca}_{9} \mathrm{Nd}\left(\mathrm{PO}_{4}\right)_{5}\left(\mathrm{SiO}_{4}\right) \mathrm{F}_{2}\right)$ will be noted Nd-britholites in the text and that containing simultaneously neodymium and thorium (e.g. $\left.\mathrm{Ca}_{9} \mathrm{Nd}_{1-x} \mathrm{Th}_{x}\left(\mathrm{PO}_{4}\right)_{5-x}\left(\mathrm{SiO}_{4}\right)_{1+x} \mathrm{~F}_{2}\right)$ will be called $(\mathrm{Nd}, \mathrm{Th})$-britholite and the expected $x$ value will always be given.

\section{Experimental}

\subsection{Preparation of the samples}

All the chemicals used for the synthesis of $(\mathrm{Nd}, \mathrm{Th})$-britholites $\left(\mathrm{Nd}_{2} \mathrm{O}_{3} ; \mathrm{CaF}_{2} ; \mathrm{ThO}_{2}\right.$; $\left.\mathrm{Ca}\left(\mathrm{HPO}_{4}\right) \cdot 2 \mathrm{H}_{2} \mathrm{O} ; \mathrm{SiO}_{2} ; \mathrm{CaCO}_{3}\right)$ were of proanalysis grade. The final samples were prepared through dry chemical methods involving an initial mixture of $\mathrm{Nd}_{2} \mathrm{O}_{3} / \mathrm{CaF}_{2} / \mathrm{ThO}_{2} / \mathrm{Ca}_{2} \mathrm{P}_{2} \mathrm{O}_{7} /$ $\mathrm{SiO}_{2} / \mathrm{CaCO}_{3}$ according to the global reaction:

$$
\frac{1}{4} \mathrm{Nd}_{2} \mathrm{O}_{3}+\frac{9}{4} \mathrm{Ca}_{2} \mathrm{P}_{2} \mathrm{O}_{7}+\frac{7}{2} \mathrm{CaCO}_{3}+\mathrm{CaF}_{2}+\frac{3}{2} \mathrm{SiO}_{2}+\frac{1}{2} \mathrm{ThO}_{2} \rightarrow \mathrm{Ca}_{9} \mathrm{Nd}_{0.5} \mathrm{Th}_{0.5}\left(\mathrm{PO}_{4}\right)_{4.5}\left(\mathrm{SiO}_{4}\right)_{1.5} \mathrm{~F}_{2}+\frac{7}{2} \mathrm{CO}_{2} \uparrow
$$


Prior to perform the synthesis, neodymium oxide was first heated at $1000^{\circ} \mathrm{C}$ for 3 hours to eliminate the presence of neodymium hydroxide. Calcium diphosphate was prepared from $\mathrm{Ca}\left(\mathrm{HPO}_{4}\right) \cdot 2 \mathrm{H}_{2} \mathrm{O}$ by heating at $1000^{\circ} \mathrm{C}$ for 3 hours.

The capability of thorium to be incorporated in the britholite structure was evaluated through the use of several initial reagents. There were mainly oxide $\left(\mathrm{ThO}_{2}\right.$ prepared by calcination of $\mathrm{Th}\left(\mathrm{C}_{2} \mathrm{O}_{4}\right)_{2} \cdot n \mathrm{H}_{2} \mathrm{O}$ at $1000^{\circ} \mathrm{C}$ for 10 hours $)$ or phosphates (e.g. $\alpha-\mathrm{ThP}_{2} \mathrm{O}_{7}$ prepared from a mixture of $\mathrm{Th}\left(\mathrm{NO}_{3}\right)_{4}$ and $\mathrm{H}_{3} \mathrm{PO}_{4}$ concentrated solutions in a mole ratio $\mathrm{Th} / \mathrm{P}$ equal to $1 / 2$, evaporated then finally calcinated at $800^{\circ} \mathrm{C}$ for 12 hours; or $\beta$-TPD obtained from a low temperature crystallized precursor $\mathrm{Th}_{2}\left(\mathrm{PO}_{4}\right)_{2}\left(\mathrm{HPO}_{4}\right) \cdot \mathrm{H}_{2} \mathrm{O}$ (called TPHPH) by firing at $1000^{\circ} \mathrm{C}$ for 12 hours). As an example, the reaction considered from $\alpha-\mathrm{ThP}_{2} \mathrm{O}_{7}$ can be written:

$$
\frac{1}{4} \mathrm{Nd}_{2} \mathrm{O}_{3}+\frac{7}{4} \mathrm{Ca}_{2} \mathrm{P}_{2} \mathrm{O}_{7}+\frac{9}{2} \mathrm{CaCO}_{3}+\mathrm{CaF}_{2}+\frac{3}{2} \mathrm{SiO}_{2}+\frac{1}{2} \mathrm{ThP}_{2} \mathrm{O}_{7} \rightarrow \mathrm{Ca}_{9} \mathrm{Nd}_{0.5} \mathrm{Th}_{0.5}\left(\mathrm{PO}_{4}\right)_{4.5}\left(\mathrm{SiO}_{4}\right)_{1.5} \mathrm{~F}_{2}+\frac{9}{2} \mathrm{CO}_{2} \uparrow
$$

Two kinds of syntheses were performed. The first one involved a manual grinding of the powders in acetone for 15 minutes. It was followed by the evaporation of the solvent then finally by a heating treatment at $1400^{\circ} \mathrm{C}$ for 6 hours under inert atmosphere (argon).

The second way was significantly different from the previous one since it involved mechanical grinding steps of the powders in a zirconia crusher for 15 minutes. The frequency of the oscillations of the crusher (RETSCH MM200) varied from 0 to $30 \mathrm{~Hz}$, depending on the grinding efficiency expected. The ground mixture was thus heated at $1400^{\circ} \mathrm{C}$ for 6 hours under inert atmosphere (argon) in a PYROX HM 40 furnace with heating and cooling rates of $5^{\circ} \mathrm{C} \cdot \min ^{-1}$

In order to avoid any reaction between silica and alumina which was systematically observed in a first series of experiments, all the powders were heated in platinum or in alumina lined by platinum boats. 
The use of manual grinding always led to less homogeneous samples compared to mechanical grinding of the initial reagents. For this reason, the major part of the samples was prepared through the second way of synthesis.

\subsection{Characterization of the powders}

The specific area of the powders was measured with a Coulter SA 3100 apparatus using the B.E.T. method (nitrogen adsorption at $77 \mathrm{~K}$ ). TGA and DTA experiments were performed with a Setaram TG 92-16 apparatus under inert atmosphere (argon) with a heating rate of $10^{\circ} \mathrm{C} \cdot \mathrm{min}^{-1}$. The X-Ray powder Diffraction (XRD) patterns were collected with a Bruker AXS D8 Advance diffractometer system using $\mathrm{Cu} \mathrm{K}_{\alpha}$ rays $(\lambda=1.5418 \AA)$.

The Electron Probe MicroAnalyses (EPMA) were carried out using a Cameca SX 50 or a Cameca SX 100 apparatus with an acceleration voltage of $15 \mathrm{kV}$ and a current intensity of $10 \mathrm{nA}$. Several calibration standards were used. They were mainly topaze $\mathrm{Al}_{2} \mathrm{SiO}_{4} \mathrm{~F}_{2}\left(\mathrm{~K}_{\alpha}\right.$ ray of fluorine), orthose $\mathrm{KAlSi}_{3} \mathrm{O}_{8}\left(\mathrm{~K}_{\alpha}\right.$ ray of silicon), monazite $\mathrm{LaPO}_{4}\left(\mathrm{~K}_{\alpha}\right.$ ray of phosphorus), wollastonite $\mathrm{Ca}_{2} \mathrm{SiO}_{4}\left(\mathrm{~K}_{\alpha}\right.$ ray of calcium), monazite $\mathrm{NdPO}_{4}\left(\mathrm{~L}_{\alpha}\right.$ ray of neodymium) and thoria $\mathrm{ThO}_{2}\left(\mathrm{M}_{\alpha}\right.$ ray of thorium). SEM micrographs were carried out with a Hitachi S2500 scanning electron microscope.

\section{Results and discussion}

\subsection{Optimization of the conditions of synthesis}

The preparation of $(\mathrm{Nd}, \mathrm{Th})$-britholite samples with $x=0.5$ was optimized by the study of two important parameters: the thorium reagent used, on the one hand, and the grinding conditions, on the other hand. The purpose was to improve the final homogeneity of the 
samples in respect to the Nd-britholite way of synthesis based on a manual grinding in acetone described in the literature [23].

\subsubsection{Influence of the thorium reagent}

Several thorium reagents were considered: $\mathrm{ThO}_{2}, \alpha-\mathrm{ThP}_{2} \mathrm{O}_{7}$ and $\beta$-TPD. All the samples were prepared thanks to a manual grinding before heating treatment. After each heating steps, XRD patterns were recorded. They only revealed the presence of the XRD lines of the britholite structure [25] excluding the formation of secondary phases. However, in the first unsuccessful syntheses where thorium was not incorporated in the britholite structure, it was still present as $\mathrm{ThO}_{2}$ (JCPDS file $\mathrm{n}^{\circ}$ 42-1462) consecutively to the decomposition of thorium phosphates at this heating temperature.

EPMA experiments carried out on the three compounds (Table 1) confirmed the results observed from XRD. Indeed, the major part of thorium was incorporated in the britholite structure for the three reagents considered. A more accurate analysis of the results revealed that the samples were heterogeneous since two average compositions of britholite were evidenced. The composition of the first one (major phase) was consistent with that expected while the second one (minor phase) was enriched in thorium, neodymium and silicon (particularly when using $\mathrm{ThO}_{2}$ and $\alpha-\mathrm{ThP}_{2} \mathrm{O}_{7}$ as initial Th-reagents). Both phases kept the mole ratio $(\mathrm{Si}+\mathrm{P}) /(\mathrm{Ca}+\mathrm{Nd}+\mathrm{Th})$ near to 0.6 necessary to ensure the charge compensation in the britholite structure.

The incorporation rate of thorium was mainly dependent on the specific surface area of the initial Th-reagent used (thus on its reactivity). Indeed, $\mathrm{ThO}_{2}$ which exhibited the highest specific area (S.A. $=8 \mathrm{~m}^{2} \cdot \mathrm{g}^{-1}$ instead of S.A. $=4-5 \mathrm{~m}^{2} \cdot \mathrm{g}^{-1}$ for $\beta$-TPD and S.A. $=3.3 \mathrm{~m}^{2} \cdot \mathrm{g}^{-1}$ for $\alpha-\mathrm{ThP}_{2} \mathrm{O}_{7}$ ) lead to more homogeneous samples consequently to a better incorporation of 
thorium. Thorium dioxide with these physico-chemical properties was thus preferred as the initial Th-reagent to follow the study.

\subsubsection{Influence of the grinding step}

In order to increase the reactivity of the initial precursors and to improve the homogeneity of the final compounds prepared, several conditions of mechanical grinding were studied (especially to improve the grinding efficiency). Three samples were prepared using different sets of grinding conditions: manual grinding in acetone for 15 minutes or two mechanical grindings ( $15 \mathrm{~Hz}$ or $30 \mathrm{~Hz}$ for 15 minutes).

The influence of the grinding step on the specific surface area is really obvious. Indeed, while the mixture of the reagents (before grinding) presented a specific surface area of $0.8 \pm$ $0.1 \mathrm{~m}^{2} \cdot \mathrm{g}^{-1}$, this one was increased up to $1.3 \pm 0.1 \mathrm{~m}^{2} \cdot \mathrm{g}^{-1}$ after a manual grinding in acetone for 15 minutes then multiplied by a factor of 3 to 7 when making mechanical grinding steps (S.A. $=2.5 \pm 0.1 \mathrm{~m}^{2} \cdot \mathrm{g}^{-1}$ after grinding at $15 \mathrm{~Hz} ; \mathrm{S} . \mathrm{A} .=4.0 \pm 0.1 \mathrm{~m}^{2} \cdot \mathrm{g}^{-1}$ after grinding at $30 \mathrm{~Hz}$ )

The XRD patterns of these three (Nd,Th)-britholite samples (with $x=0.5$ ) matched well with that recorded for Nd-britholite. The EPMA experiments (Table 1) showed that the incorporation of thorium reached $10 \mathrm{wt} . \%$. They also revealed that the solid prepared using

manual grinding exhibited two britholite compositions: $\mathrm{Ca}_{9.13} \mathrm{Nd}_{0.45} \mathrm{Th}_{0.50}\left(\mathrm{PO}_{4}\right)_{4.62}\left(\mathrm{SiO}_{4}\right)_{1.38} \mathrm{~F}_{1.48} \mathrm{O}_{0.37}$ (which corresponds to the expected composition) and Th- and Nd-enriched phase of formula $\mathrm{Ca}_{8.30} \mathrm{Nd}_{0.89} \mathrm{Th}_{0.91}\left(\mathrm{PO}_{4}\right)_{3.58}\left(\mathrm{SiO}_{4}\right)_{2.44} \mathrm{~F}_{1.19} \mathrm{O}_{0.58}$. When using a mechanical grinding (either for 15 minutes at $15 \mathrm{~Hz}$ or at $30 \mathrm{~Hz}$ ), the samples appeared more homogeneous with an average composition of $\mathrm{Ca}_{8.96} \mathrm{Nd}_{0.51} \mathrm{Th}_{0.52}\left(\mathrm{PO}_{4}\right)_{4.48}\left(\mathrm{SiO}_{4}\right)_{1.49} \mathrm{~F}_{0.11} \mathrm{O}_{1.02}$ near to that expected [28]. This important improvement of the samples homogeneity was clearly attributed to the mechanical grinding step. It was confirmed by the comparison of the micrographies of manually and mechanically 
ground $(30 \mathrm{~Hz})$ samples (Fig. 1a and Fig. 1b, respectively) which revealed some heterogeneities on the first sample. On the basis of these results, all the samples were prepared from $\mathrm{ThO}_{2}$ and thanks to mechanical grinding (15 minutes, $\left.30 \mathrm{~Hz}\right)$.

\subsection{Incorporation of thorium versus the heating temperature}

Considering the conditions of synthesis previously defined (mechanical-grinding at 30 $\mathrm{Hz}$ for 15 minutes followed by calcination at $1400^{\circ} \mathrm{C}$ for 6 hours), it was interesting to understand the successive chemical steps leading to the incorporation of thorium in the britholite structure. So, this incorporation was followed versus the heating temperature for $\mathrm{Ca}_{9} \mathrm{Nd}_{0.5} \mathrm{Th}_{0.5}\left(\mathrm{PO}_{4}\right)_{4.5}\left(\mathrm{SiO}_{4}\right)_{1.5} \mathrm{~F}_{2}$ prepared from a mixture of powdered $\mathrm{CaF}_{2}, \mathrm{Nd}_{2} \mathrm{O}_{3}, \mathrm{SiO}_{2}$, $\mathrm{CaCO}_{3}, \mathrm{Ca}_{2} \mathrm{P}_{2} \mathrm{O}_{7}$ and $\mathrm{ThO}_{2}$. Prior to make the heat treatment, the mixture was mechanically ground for 15 minutes at a frequency of $30 \mathrm{~Hz}$ in order to get the optimal reactivity of the powder then heated between $800^{\circ} \mathrm{C}$ and $1400^{\circ} \mathrm{C}$ for 6 hours.

\subsubsection{TGA - DTA experiments}

TGA and DTA experiments were performed using $\mathrm{CaO}$ instead of $\mathrm{CaCO}_{3}$ because of the high contribution of $\mathrm{CO}_{2}$ release coming from the decomposition of $\mathrm{CaCO}_{3}$ in the global weight losses. The following reaction was thus considered for TGA-DTA:

$$
\frac{1}{4} \mathrm{Nd}_{2} \mathrm{O}_{3}+\frac{9}{4} \mathrm{Ca}_{2} \mathrm{P}_{2} \mathrm{O}_{7}+\frac{7}{2} \mathrm{CaO}+\mathrm{CaF}_{2}+\frac{3}{2} \mathrm{SiO}_{2}+\frac{1}{2} \mathrm{ThO}_{2} \rightarrow \mathrm{Ca}_{9} \mathrm{Nd}_{0.5} \mathrm{Th}_{0.5}\left(\mathrm{PO}_{4}\right)_{4.5}\left(\mathrm{SiO}_{4}\right)_{1.5} \mathrm{~F}_{2}
$$

The TGA curve (Fig. 2) exhibited a weight loss of $2 \%$ between $350^{\circ} \mathrm{C}$ and $450^{\circ} \mathrm{C}$ associated to an endothermic peak on the DTA curve, corresponding to the loss of water molecules associated to the decomposition of calcium oxide hydroxide $\mathrm{CaO}_{1-x}(\mathrm{OH})_{2 x}$ into anhydrous calcium oxide $\mathrm{CaO}$ (which exhibits an important hygroscopic character). 
For higher temperatures, only a small weight loss $(0.5 \%)$ was observed between $1070^{\circ} \mathrm{C}$ and $1200^{\circ} \mathrm{C}$. It was associated to a broad endothermic peak (Fig. 2), which was attributed to the formation of britholite. These results appeared in good agreement with that reported by Audubert et al. who reported the formation of Nd-britholite samples at $1200^{\circ} \mathrm{C}$ [29].

\subsubsection{XRD analysis}

In order to follow the formation of britholites, XRD patterns were recorded on samples heated at several temperatures ranging from $500^{\circ} \mathrm{C}$ to $1400^{\circ} \mathrm{C}$ with a step of $100^{\circ} \mathrm{C}$ (Fig. 3). The associated refined unit cell parameters are reported in Table 2 and their variations versus the heating temperature are summarized in Fig. 4. Correlatively, the chemical composition was followed by EPMA versus the heating temperature (Fig. 5).

From these results, several steps were evidenced in the thorium incorporation. Apatite structure was first formed between $800^{\circ} \mathrm{C}$ and $900^{\circ} \mathrm{C}$ while neither thorium nor silicates participate to the "elaboration" of the structure as indicated from the refined unit cell parameters and from the EPMA experiments. These analyses confirmed the formation of fluorapatite $\mathrm{Ca}_{10}\left(\mathrm{PO}_{4}\right)_{6} \mathrm{~F}_{2}$ containing only small amounts of silicate, neodymium and thorium at these temperatures. Both neodymium and thorium were still present in the oxide form in the mixture, as shown from the $\mathrm{XRD}$ patterns while $\mathrm{SiO}_{2}$, which remained amorphous, was detected with difficulty.

For $T \geq 1000^{\circ} \mathrm{C}, \mathrm{Nd}_{2} \mathrm{O}_{3}$ was not still detected in the XRD patterns while the intensity of the XRD lines associated to $\mathrm{ThO}_{2}$ strongly decreased, showing the progressive incorporation of thorium in the britholite structure between $1000^{\circ} \mathrm{C}$ and $1100^{\circ} \mathrm{C}$ (Fig. 3). Simultaneously, the weight percent of thorium, neodymium and silicon significantly increased in the britholite structure as shown by the refined unit cell parameters (Fig. 4) and the elementary weight 
loadings (Fig. 5). Above $1100^{\circ} \mathrm{C}$, the refined unit cell parameters tend to that of the final (Nd,Th)-britholite sample (with $x=0.5$ ) (Fig. 4) while the elementary weight percent are in good agreement with that expected (Fig. 5). However, the EPMA analyses revealed that the compounds were more homogeneous when increasing the temperature up to $1400^{\circ} \mathrm{C}$.

Previous studies carried out on Nd-britholites, prepared from a mixture of reagents manually ground, showed that the incorporation of neodymium occurred above $1200^{\circ} \mathrm{C}$. Audubert explained the formation of Nd-britholite by the formation of intermediates such as $\mathrm{Ca}_{2} \mathrm{SiO}_{4}, \mathrm{NdPO}_{4}$, and $\mathrm{Ca}_{3}\left(\mathrm{PO}_{4}\right)_{2}$ which reacted with $\mathrm{CaF}_{2}$ to form the fluorapatite below $1000^{\circ} \mathrm{C}$. The Nd-incorporation was only efficient above $1200^{\circ} \mathrm{C}$ where both neodymium and silicate ions participated to the formation of the britholite structure [29].

\subsection{Preparation of $\mathrm{Ca}_{9} \mathrm{Nd}_{1-x} \mathrm{Th}_{x}\left(\mathrm{PO}_{4}\right)_{5-x}\left(\mathrm{SiO}_{4}\right)_{1+x} \mathrm{~F}_{2}$ solid solutions}

On the basis of the previous results, the incorporation of thorium in britholite was studied through the elaboration of $\mathrm{Ca}_{9} \mathrm{Nd}_{1-x} \mathrm{Th}_{x}\left(\mathrm{PO}_{4}\right)_{5-x}\left(\mathrm{SiO}_{4}\right)_{1+x} \mathrm{~F}_{2}$ and $\mathrm{Ca}_{9} \mathrm{Nd}_{1-x} \mathrm{Th}_{x}\left(\mathrm{PO}_{4}\right)_{5}\left(\mathrm{SiO}_{4}\right) \mathrm{F}_{2-x} \mathrm{O}_{x}$ samples for $0 \leq x \leq 1$, considering the coupled substitutions $\left(\mathrm{Nd}^{3+}, \mathrm{PO}_{4}{ }^{3-}\right) \Leftrightarrow\left(\mathrm{Th}^{4+}, \mathrm{SiO}_{4}{ }^{4-}\right)$ and $\left(\mathrm{Nd}^{3+}, \mathrm{F}^{-}\right) \Leftrightarrow\left(\mathrm{Th}^{4+}, \mathrm{O}^{2-}\right)$, respectively.

\subsubsection{Synthesis of $\mathrm{Ca}_{9} N d_{1-x} \mathrm{Th}_{x}\left(\mathrm{PO}_{4}\right)_{5-x}\left(\mathrm{SiO}_{4}\right)_{1+x} \mathrm{~F}_{2}$ solid solution}

The XRD patterns of $\mathrm{Ca}_{9} \mathrm{Nd}_{1-x} \mathrm{Th}_{x}\left(\mathrm{PO}_{4}\right)_{5-x}\left(\mathrm{SiO}_{4}\right)_{1+x} \mathrm{~F}_{2}$ are reported on Fig. 6 for several $x$ values ranging from 0 to $20 \mathrm{wt} \%(\mathrm{Th})$ in the solid. All these patterns appeared in good agreement with that reported for $\mathrm{Ca}_{9} \mathrm{Nd}\left(\mathrm{PO}_{4}\right)_{5}\left(\mathrm{SiO}_{4}\right) \mathrm{F}_{2}$ (JCPDS file $\mathrm{n}^{\circ}$ 87-0480 and [25]). No diffraction line, which could indicate the presence of $\mathrm{ThO}_{2}$ or $\mathrm{Nd}_{2} \mathrm{O}_{3}$, was observed. From these results, the reaction between all the initial reagents appeared to be complete. In order to complete the characterization, the samples were also examined by $\mu$-Raman and infra-red 
absorption spectroscopies: all the vibrations band observed can be assigned to the vibrations of $\mathrm{PO}_{4}$ or $\mathrm{SiO}_{4}$ characteristic in apatitic structure (Fig. 7).

The samples were characterized by EPMA (Table 5) which revealed homogeneous and single phase samples for all the compositions examined (up to $20 \mathrm{wt} . \%$ ). For each sample, the $x$ values determined from the amounts of $\mathrm{Nd}, \mathrm{Th}, \mathrm{Si}$ and $\mathrm{P}$ in the samples considering the formula $\mathrm{Ca}_{9} \mathrm{Nd}_{1-x} \mathrm{Th}_{x}\left(\mathrm{PO}_{4}\right)_{5-x}\left(\mathrm{SiO}_{4}\right)_{1+x} \mathrm{~F}_{2}$ led to the average value $\bar{x}$ (Table 5) and appeared in good agreement with the expected values.

The corresponding refined unit cell parameters are gathered in Table 3 while their variations versus the average substitution rate are reported in Fig. 8 and in Table 4.

For the $\left(\mathrm{Nd}^{3+}, \mathrm{PO}_{4}{ }^{3-}\right) \Leftrightarrow\left(\mathrm{Th}^{4+}, \mathrm{SiO}_{4}{ }^{4-}\right)$ coupled substitution, the unit cell parameters increase linearly when substituting neodymium by thorium in the samples. Nevertheless, this small increase $(\Delta \mathrm{V} / \mathrm{V} \sim 0.7 \%$ from $x=0$ to $x=1)$ could result from two antagonistic variations: replacement of neodymium $\left({ }^{\mathrm{VII}} \mathrm{r}_{\mathrm{Nd}}=1.05 \AA\right.$ [30] $)$ by the smaller thorium $\left({ }^{\mathrm{VII}} \mathrm{r}_{\mathrm{Th}}=\right.$ $1.00 \AA[30]$ ) and of phosphate group by larger silicate entities [28]. Indeed, the average lengths of $\mathrm{P}-\mathrm{O}$ and $\mathrm{Si}-\mathrm{O}$ bonds in $\mathrm{XO}_{4}$ groups are usually equal to $1.53 \pm 0.03 \AA$ for $\mathrm{P}-\mathrm{O}$ bond and $1.61 \pm 0.02 \AA$ for Si-O bond, leading to larger tetrahedra for silicate groups [31].

The observations of the samples by SEM (Fig. 9) showed that for low values of substitution rates $(x=0$ or $x=0.25)$, i.e. for low silicated britholites, the samples presented essentially grains with rounded form. For higher $x$ values, powders exhibited needle-like grains of 5-10 $\mu \mathrm{m}$ in length and 1-2 $\mu \mathrm{m}$ in width. The same observations were already done by Boyer et al. for lanthanum bearing britholites when studying full phosphated or full silicated apatites [32]. 
3.3.2. Influence of nature of the substitution $\left(\mathrm{Nd}^{3+}, \mathrm{F}^{-}\right) \Leftrightarrow\left(\mathrm{Th}^{4+}, \mathrm{O}^{2-}\right) v s .\left(\mathrm{Nd}^{3+}, \mathrm{PO}_{4}^{3-}\right) \Leftrightarrow$ $\left(\mathrm{Th}^{4+}, \mathrm{SiO}_{4}^{4-}\right)$.

In order to evidence the importance of the coupled substitution, a second kind of substitution was examined. It consisted in the substitution $\left(\mathrm{Nd}^{3+}, \mathrm{F}^{-}\right) \Leftrightarrow\left(\mathrm{Th}^{4+}, \mathrm{O}^{2-}\right)$, leading to the formation of $\mathrm{Ca}_{9} \mathrm{Nd}_{1-x} \mathrm{Th}_{x}\left(\mathrm{PO}_{4}\right)_{5}\left(\mathrm{SiO}_{4}\right)_{1} \mathrm{~F}_{2-x} \mathrm{O}_{x}$ samples $(0 \leq x \leq 1)$ in which the mole ratio $\mathrm{PO}_{4} / \mathrm{SiO}_{4}$ was kept constant and equal to $5 / 1$ (the charge compensation being ensured by oxide anion in these samples). All the other parameters (Th-reagent, grinding step ...) previously optimized were kept constant.

The XRD patterns revealed that the samples were polyphased, composed by britholite, thorium dioxide, and huttonite $\mathrm{ThSiO}_{4}$ for the highest $x$ values.

The EPMA results (Table 6 and Fig. 10) revealed a good accuracy between the experimental weight percents compared to that expected for $x \leq 0.5$. On the contrary, thorium was partly incorporated in the britholite structure for $x \geq 0.66$ (pointed by the dash box in Fig. 10) leading to polyphase samples. The weight percent of thorium loaded in these samples reached only 9 to $11 \mathrm{wt} . \%$ instead of 13 to $19 \mathrm{wt} . \%$ expected. Simultaneously, the mole ratio $\mathrm{PO}_{4} / \mathrm{SiO}_{4}$, which remained close to $5 / 1$ confirmed that the stoichiometry of britholites was kept.

The variations of the refined unit cell parameters (Table 7 and Fig. 11) remained very low for $x \leq 0.5$ and did not vary significantly for $x \geq 0.66$. Since the mole ratio $\mathrm{PO}_{4} / \mathrm{SiO}_{4}$ remained constant, this variation was only correlated to the replacement of neodymium by thorium in the structure.

The comparison of both kinds of substitutions studied $\left(\left(\mathrm{Nd}^{3+}, \mathrm{PO}_{4}{ }^{3-}\right) \Leftrightarrow\left(\mathrm{Th}^{4+}, \mathrm{SiO}_{4}{ }^{4-}\right)\right.$ and $\left.\left(\mathrm{Nd}^{3+}, \mathrm{F}^{-}\right) \Leftrightarrow\left(\mathrm{Th}^{4+}, \mathrm{O}^{2-}\right)\right)$ clearly evidenced the benefit of using the first one (Fig. 12) which led to accurate and expected results for all the chemical compositions considered. On 
the contrary, for the second way, only samples with $x \leq 0.5$ were obtained as pure and single phase compounds indicating a limit of loading of around 10-11 wt.\%.

\section{Conclusion}

From the results obtained, the incorporation of thorium in the britholite structure occurred above $1100^{\circ} \mathrm{C}$ but it was necessary to fire the initial mixture at $1400^{\circ} \mathrm{C}$ for 6 hours to prepare single phase and homogeneous compounds. The incorporation of thorium in the britholite structure was observed for all the thorium reagents used (oxide or phosphate). The use of a mechanical grinding step ( 15 minutes, $30 \mathrm{~Hz}$ ) allowed to increase the specific surface area (thus the reactivity) of the mixture and led to a better homogeneity of the final samples. The optimized conditions were fixed to a mechanical grinding (15 minutes, $30 \mathrm{~Hz}$ ) followed by a heat treatment at $1400^{\circ} \mathrm{C}$ for 6 hours.

The incorporation of thorium in the structure is probably possible due to the small differences of ionic radius between calcium, neodymium and thorium $\left({ }^{\mathrm{VII}} \mathrm{r}_{\mathrm{Ca}^{2+}}=1.06 \AA\right.$, ${ }^{\mathrm{VII}} \mathrm{r}_{\mathrm{Nd}}{ }^{3+}=1.05 \AA$ and $\left.{ }^{\mathrm{VII}} \mathrm{r}_{\mathrm{Th}}{ }^{4+}=1.00 \AA[30]\right)$. In order to ensure the quantitative incorporation of thorium, it appeared necessary to consider the coupled substitution $\left(\mathrm{Nd}^{3+}, \mathrm{PO}_{4}{ }^{3-}\right) \Leftrightarrow\left(\mathrm{Th}^{4+}\right.$, $\left.\mathrm{SiO}_{4}{ }^{4-}\right)$ instead of the substitution $\left(\mathrm{Nd}^{3+}, \mathrm{F}\right) \Leftrightarrow\left(\mathrm{Th}^{4+}, \mathrm{O}^{2-}\right)$. Indeed, by the first way, homogeneous and single phase solid solutions were prepared from $\mathrm{Ca}_{9} \mathrm{Nd}\left(\mathrm{PO}_{4}\right)_{5}\left(\mathrm{SiO}_{4}\right) \mathrm{F}_{2}$ to $\mathrm{Ca}_{9} \mathrm{Th}\left(\mathrm{PO}_{4}\right)_{4}\left(\mathrm{SiO}_{4}\right)_{2} \mathrm{~F}_{2}$ leading to the whole neodymium substitution. The associated small increase of the unit cell parameters results from the simultaneous replacement of phosphate groups by bigger silicate. It was accompanied by a significant change in the grain morphology.

These results contrast with that obtained when using the coupled substitution $\left(\mathrm{Nd}^{3+}, \mathrm{F}\right) \Leftrightarrow\left(\mathrm{Th}^{4+}, \mathrm{O}^{2-}\right)$ which confirmed a limitation of about 10 wt. $\%$ in the 
Th-substitution, the samples being polyphase for higher weight loading. These problems were associated to some problems occurring in the charge balance because of the partial substitution of fluoride ions by oxide ions.

On the basis of the results reported in this paper, the sintering of $(\mathrm{Nd}, \mathrm{Th})$-britholite (with $x=0.5$ ) was undertaken in order to perform the densification of the samples. These sintered dense pellets were leached to study the chemical durability of this potential waste storage matrix [33]. Furthermore, it also appeared interesting to study the incorporation of a smaller tetravalent actinide which could exhibit several oxidation states during the synthesis, the sintering process and the leaching tests. This naturally led us to study the incorporation of uranium in the britholite structure. 


\section{References}

[1] C. Guy, F. Audubert, J.E. Lartigue, C. Latrille, T. Advocat, C. Fillet, C. R. Physique 3 (2002) 827.

[2] N. Dacheux, N. Clavier, A.C. Robisson, O. Terra, F. Audubert, J.E. Lartigue, C. Guy, C. R. Chimie 7 (2004) 1141.

[3] V. Sère, in: Géochimie des minéraux néoformés à Oklo (Gabon), histoire géologique du bassin d'Oklo: une contribution pour les études de stockages géologiques de déchets radioactifs, $\mathrm{PhD}$ thesis, Université Paris VII, 1996.

[4] R. Bros, J. Carpéna, V. Sère, A. Beltritti, Radiochim. Acta 74 (1996) 277.

[5] J. Carpena, J.R. Kienast, K. Ouzegane, C. Jehanno, Geol. Soc. Amer. Bull. 100 (1988) 1237.

[6] J. Carpéna, in: P. Van den haute and F. De Corte (Eds.), Advances in Fission-Track Geochronoly, Kluwer Academic Publishers, 1998, p. 81.

[7] N. Kalsbeek, S. Larsen, J. G. Ronsbo, Z. Kristall. 191 (1990) 249.

[8] E.A. Genkina, Y.A. Malinovskii, A.P. Khomyakov, Sov. Phys. Crystall. 36[1] (1991) 19.

[9] A.C. Tas, M. Akinc, Powder Diff. 7(4) (1992) 219.

[10] D.C. Noe, J.M. Hughes, A.N. Mariano, J.W. Drexler, A. Kato, Z. Kristall. 206 (1993) 233.

[11] J. Rakovan, R.J. Reeder, Geoch. Cosmochim. Acta 60[22] (1996) 4435.

[12] S. Ogihara, Sedimentary Geol. 125 (1999) 69.

[13] J.S. Compton, R.A. White, M. Smith, Chem. Geol. 201 (2003) 239.

[14] O. Fujino, S. Umetani, E. Ueno, K. Shigeta, T. Matsuda, Anal. Chim. Acta 420 (2000) 65.

[15] P.W. Reiners, K.A. Farley, Earth and Planetary Sc. Letters 188 (2001) 413.

[16] M. Jolivet, T. Dempser, R. Cox, C. R. Geosciences 335 (2003) 899.

[17] G. Engel, Mater. Res. Bull. 13 (1978) 43.

[18] R. El Ouenzerfi, M.T. Cohen Adad, C. Goutaudier, G. Panczer., Solid State Ionics 176 (2004) 225. 
[19] E.R. Vance, C.J. Ball, B.D. Begg, M.L. Carter, R.A. Day, G.J. Thorogood, J. Am. Ceram. Soc. 86[7] (2003) 1223.

[20] W.J. Weber, F.P. Roberts, Nucl. Technol. 60 (1983) 178.

[21] W.J. Weber, J. Am. Ceram. Soc. 65[11] (1982) 544.

[22] W.J. Weber, R.C. Ewing, A. Meldrum, J. Nucl. Mater. 250 (1997) 147.

[23] L. Boyer, in: Synthèses et caractérisations d'apatites phospho-silicatées aux terres rares : application au nucléaire, $\mathrm{PhD}$ thesis, INP Toulouse, 1998.

[24] S. Soulet, J. Carpena, J. Chaumont, J.C. Krupa, M. O. Ruault, J. Nucl. Mater. 299 (2001) 227.

[25] L. Boyer, J.M. Savariault, J. Carpéna, J.L. Lacout, Acta Cryst. C54 (1998) 1057.

[26] F. Audubert, D. Bernache-Assolant, in: P. Vincenzini (Ed.), Advances in Science and Technology - Proceedings of the $10^{\text {th }}$ International Ceramics Congress-CIMTEC 2002, Vol. 31 Part B, Faenza, Italy, 2002, p. 61.

[27] D. Bregiroux, F. Audubert, E. Champion, D. Bernache-Assolant, Mat. Lett. 57 (2003) 3526.

[28] O. Terra, N. Dacheux, F. Audubert, C. Guy, R. Podor, Mat. Res. Soc. Symp. Proc. 802 (2004), 119.

[29] F. Audubert, Private Communication.

[30] R.D. Shannon, Acta Cryst. A32 (1976) 751.

[31] N.N. Greenwood, A. Earnshaw, in: The Actinides Elements ( $\mathrm{Z}=90-103)$. Chemistry of the Elements, Pergamon Press, 1990, p. 1450.

[32] L. Boyer, J. Carpéna, J-L. Lacout, Solid State Ionics 95 (1997) 121.

[33] O. Terra, N. Dacheux, F. Audubert, R. Podor, J. Nucl. Mater., to be published (2005). 
Table 1. Results of EPMA analysis of (Nd,Th)-britholites (with $x=0.5$ ) for several Th-reagents and several grinding conditions for $\mathrm{ThO}_{2}$.

\begin{tabular}{|c|c|c|c|c|c|c|c|c|}
\hline \multirow[t]{3}{*}{ Reagent } & \multirow[b]{3}{*}{ Calc. } & \multirow{3}{*}{$\begin{array}{l}\beta \text {-TPD } \\
\text { manual } \\
\text { grinding }\end{array}$} & \multirow{2}{*}{\multicolumn{2}{|c|}{$\frac{\alpha-\mathrm{ThP}_{2} \mathrm{O}_{7}}{\text { manual grinding }}$}} & \multicolumn{4}{|c|}{$\mathrm{ThO}_{2}$} \\
\hline & & & & & \multicolumn{2}{|c|}{ manual grinding } & \multirow{2}{*}{$\begin{array}{l}\text { vibro-grinding } \\
15 \mathrm{~Hz}-15 \mathrm{~min}\end{array}$} & \multirow{2}{*}{$\begin{array}{l}\text { vibro-grinding } \\
30 \mathrm{~Hz}-15 \mathrm{~min}\end{array}$} \\
\hline & & & Phase I (maj) & Phase II (min) & Phase I (maj) & Phase II (min) & & \\
\hline wt. $\%(\mathrm{O}) *$ & 33.2 & $34.6 \pm 0.4$ & $34.5 \pm 0.1$ & $32.3 \pm 2.0$ & $33.9 \pm 0.4$ & $31.2 \pm 0.8$ & $34.4 \pm 0.3$ & $35.1 \pm 0.3$ \\
\hline wt. \%(F) & 3.3 & $2.4 \pm 0.2$ & $2.3 \pm 0.1$ & $2.0 \pm 0.5$ & $2.5 \pm 0.1$ & $1.8 \pm 0.1$ & $1.8 \pm 0.2$ & $0.2 \pm 0.1$ \\
\hline wt. \%(Si) & 3.7 & $3.6 \pm 0.3$ & $3.5 \pm 0.2$ & $4.6 \pm 1.5$ & $3.4 \pm 0.2$ & $5.4 \pm 0.2$ & $3.9 \pm 0.2$ & $3.7 \pm 0.1$ \\
\hline wt. \%(P) & 12.1 & $12.7 \pm 0.4$ & $12.8 \pm 0.1$ & $10.3 \pm 2.8$ & $12.5 \pm 0.3$ & $8.8 \pm 0.8$ & $11.6 \pm 0.3$ & $12.2 \pm 0.1$ \\
\hline wt. \%(Ca) & 31.3 & $32.1 \pm 0.5$ & $32.0 \pm 0.6$ & $28.2 \pm 3.6$ & $31.9 \pm 0.7$ & $26.2 \pm 0.6$ & $31.4 \pm 0.5$ & $31.6 \pm 0.3$ \\
\hline wt. \%(Nd) & 6.3 & $5.4 \pm 0.4$ & $6.3 \pm 0.2$ & $11.7 \pm 6.3$ & $5.7 \pm 0.6$ & $10.1 \pm 0.8$ & $6.3 \pm 0.3$ & $6.5 \pm 0.3$ \\
\hline wt. \%(Th) & 10.1 & $9.2 \pm 0.9$ & $8.6 \pm 1.0$ & $10.9 \pm 0.9$ & $10.1 \pm 0.8$ & $16.5 \pm 2.1$ & $10.5 \pm 0.9$ & $10.6 \pm 0.4$ \\
\hline \multicolumn{9}{|l|}{ Mole ratio } \\
\hline $\mathrm{Si} / \mathrm{P}$ & 0.333 & $0.316 \pm 0.035$ & $0.305 \pm 0.016$ & $0.53 \pm 0.01$ & $0.30 \pm 0.03$ & $0.68 \pm 0.09$ & $0.37 \pm 0.02$ & $0.33 \pm 0.01$ \\
\hline $\mathrm{Nd} / \mathrm{Ca}$ & 0.056 & $0.047 \pm 0.004$ & $0.054 \pm 0.003$ & $0.12 \pm 0.01$ & $0.050 \pm 0.006$ & $0.107 \pm 0.006$ & $0.056 \pm 0.004$ & $0.057 \pm 0.003$ \\
\hline $\mathrm{Th} / \mathrm{Ca}$ & 0.056 & $0.050 \pm 0.006$ & $0.046 \pm 0.006$ & $0.07 \pm 0.02$ & $0.055 \pm 0.005$ & $0.109 \pm 0.016$ & $0.058 \pm 0.008$ & $0.058 \pm 0.002$ \\
\hline $\begin{array}{c}(\mathrm{Si}+\mathrm{P}) / \\
(\mathrm{Ca}+\mathrm{Nd}+\mathrm{Th})\end{array}$ & 0.600 & $0.61 \pm 0.01$ & $0.61 \pm 0.01$ & $0.59 \pm 0.01$ & $0.596 \pm 0.006$ & $0.60 \pm 0.02$ & $0.586 \pm 0.004$ & $0.597 \pm 0.007$ \\
\hline \multicolumn{2}{|c|}{ Expected formula } & \multicolumn{7}{|c|}{ Proposed formulae } \\
\hline $\mathrm{Ca}$ & 9 & $9.08 \pm 0.14$ & $9.09 \pm 0.17$ & $8.6 \pm 0.5$ & $9.13 \pm 0.20$ & $8.30 \pm 0.19$ & $9.06 \pm 0.14$ & $8.96 \pm 0.09$ \\
\hline $\mathrm{Nd}$ & 0.5 & $0.42 \pm 0.03$ & $0.49 \pm 0.02$ & $1.0 \pm 0.2$ & $0.45 \pm 0.05$ & $0.89 \pm 0.07$ & $0.51 \pm 0.01$ & $0.51 \pm 0.02$ \\
\hline Th & 0.5 & $0.45 \pm 0.04$ & $0.42 \pm 0.05$ & $0.6 \pm 0.5$ & $0.50 \pm 0.04$ & $0.91 \pm 0.12$ & $0.52 \pm 0.04$ & $0.52 \pm 0.02$ \\
\hline $\mathrm{PO}_{4}$ & 4.5 & $4.64 \pm 0.15$ & $4.68 \pm 0.04$ & $4.0 \pm 0.5$ & $4.62 \pm 0.11$ & $3.58 \pm 0.33$ & $4.32 \pm 0.11$ & $4.48 \pm 0.04$ \\
\hline $\mathrm{SiO}_{4}$ & 1.5 & $1.46 \pm 0.12$ & $1.43 \pm 0.08$ & $2.0 \pm 0.4$ & $1.38 \pm 0.08$ & $2.44 \pm 0.09$ & $1.59 \pm 0.08$ & $1.49 \pm 0.04$ \\
\hline $\mathrm{F}$ & 2 & $1.41 \pm 0.12$ & $1.35 \pm 0.06$ & $1.3 \pm 0.3$ & $1.48 \pm 0.06$ & $1.19 \pm 0.07$ & $1.10 \pm 0.12$ & $0.11 \pm 0.06$ \\
\hline $\mathrm{O}$ & 0 & $0.03 \pm 0.01$ & $0.11 \pm 0.01$ & $0.65 \pm 0.03$ & $0.37 \pm 0.01$ & $0.61 \pm 0.01$ & $0.66 \pm 0.01$ & $1.01 \pm 0.01$ \\
\hline
\end{tabular}

* obtained by difference 
Table 2. Variation of the refined unit cell parameters of the apatite/britholite phase versus the heating temperature (expected formula: $\mathrm{Ca}_{9} \mathrm{Nd}_{0.5} \mathrm{Th}_{0.5}\left(\mathrm{PO}_{4}\right)_{4.5}\left(\mathrm{SiO}_{4}\right)_{1.5} \mathrm{~F}_{2}$ ).

\begin{tabular}{ccccc}
\hline$T\left({ }^{\circ} \mathrm{C}\right)$ & $a(\AA)$ & $c(\AA)$ & $\mathrm{V}\left(\AA^{3}\right)$ & \multicolumn{1}{c}{$\mathrm{F}_{20}$} \\
\hline 800 & $9.367(2)$ & $6.884(1)$ & $523.1(4)$ & $84(0.0059 ; 40)$ \\
900 & $9.371(2)$ & $6.886(1)$ & $523.6(4)$ & $83(0.006 ; 40)$ \\
1000 & $9.382(2)$ & $6.896(1)$ & $525.6(4)$ & $42(0.012 ; 40)$ \\
1100 & $9.418(2)$ & $6.908(1)$ & $530.6(4)$ & $86(0.0065 ; 36)$ \\
1200 & $9.411(2)$ & $6.904(1)$ & $529.6(4)$ & $184(0.0035 ; 31)$ \\
1300 & $9.411(2)$ & $6.910(1)$ & $529.9(4)$ & $170(0.0038 ; 31)$ \\
1400 & $9.408(2)$ & $6.910(1)$ & $529.7(4)$ & $184(0.0035 ; 31)$ \\
\hline Nd-britholite [25] & $9.3938(8)$ & $6.9013(5)$ & $527.40(7)$ & --- \\
\hline
\end{tabular}


Table 3. Refined unit cell parameters and volume of $\mathrm{Ca}_{9} \mathrm{Nd}_{1-x} \mathrm{Th}_{x}\left(\mathrm{PO}_{4}\right)_{5-x}\left(\mathrm{SiO}_{4}\right)_{1+x} \mathrm{~F}_{2}$ britholites $(0 \leq \bar{x} \leq 1)$.

\begin{tabular}{ccccc}
\hline $\bar{x}$ & $a(\AA)$ & $c(\AA)$ & $\mathrm{V}\left(\AA^{3}\right)$ & $\mathrm{F}_{20}$ \\
\hline 0 & $9.401(2)$ & $6.902(1)$ & $528.3(4)$ & $195(0.0033 ; 31)$ \\
0.15 & $9.406(2)$ & $6.907(1)$ & $529.2(4)$ & $165(0.0039 ; 31)$ \\
0.21 & $9.405(2)$ & $6.905(1)$ & $529.0(4)$ & $179(0.0036 ; 31)$ \\
0.50 & $9.408(2)$ & $6.910(1)$ & $529.7(4)$ & $184(0.0035 ; 31)$ \\
0.52 & $9.412(2)$ & $6.911(1)$ & $530.2(4)$ & $150(0.0043 ; 31)$ \\
0.55 & $9.411(2)$ & $6.912(1)$ & $530.1(4)$ & $129(0.0050 ; 31)$ \\
0.71 & $9.415(2)$ & $6.911(1)$ & $530.5(4)$ & $191(0.0034 ; 31)$ \\
0.83 & $9.417(2)$ & $6.915(1)$ & $531.1(4)$ & $157(0.0041 ; 31)$ \\
1.01 & $9.421(2)$ & $6.919(1)$ & $531.8(4)$ & $115(0.0056 ; 31)$ \\
\hline
\end{tabular}


Table 4. Variation of the refined unit cell parameters and volume of $\mathrm{Ca}_{9} \mathrm{Nd}_{1-x} \mathrm{Th}_{x}\left(\mathrm{PO}_{4}\right)_{5-x}\left(\mathrm{SiO}_{4}\right)_{1+x} \mathrm{~F}_{2}(0 \leq \bar{x} \leq 1)$ versus the thorium substitution rate.

\begin{tabular}{cc}
\hline Unit cell parameter & Variation \\
\hline$a(\AA)$ & $9.4012(6)+0.019(1) \bar{x}$ \\
$c(\AA)$ & $6.9025(7)+0.015(1) \bar{x}$ \\
$\mathrm{~V}\left(\AA^{3}\right)$ & $528.3(1)+3.3(2) \bar{x}$ \\
\hline
\end{tabular}


Table 5. Results of EPMA analysis of $\mathrm{Ca}_{9} \mathrm{Nd}_{1-x} \mathrm{Th}_{\mathrm{x}}\left(\mathrm{PO}_{4}\right)_{5-x}\left(\mathrm{SiO}_{4}\right)_{1+x} \mathrm{~F}_{2}$ britholites for $0 \leq x \leq 1$.

\begin{tabular}{|c|c|c|c|c|c|c|c|c|}
\hline & \multicolumn{2}{|c|}{$x=0$} & \multicolumn{2}{|c|}{$x=0.15$} & \multicolumn{2}{|c|}{$x=0.25$} & \multicolumn{2}{|c|}{$x=0.5$} \\
\hline & Calc. & Exp. & Calc. & Exp. & Calc. & Exp. & Calc. & Exp. \\
\hline wt. $\%(O) *$ & 34.6 & $34.8 \pm 0.3$ & 34.2 & $33.7 \pm 0.4$ & 33.9 & $34.4 \pm 0.3$ & 33.2 & $35.1 \pm 0.3$ \\
\hline wt. $\%(F)$ & 3.4 & $3.3 \pm 0.1$ & 3.4 & $2.9 \pm 0.3$ & 3.4 & $2.8 \pm 0.3$ & 3.3 & $0.2 \pm 0.1$ \\
\hline wt. \%(Si) & 2.5 & $2.6 \pm 0.1$ & 2.9 & $2.9 \pm 0.1$ & 3.1 & $3.1 \pm 0.2$ & 3.7 & $3.7 \pm 0.1$ \\
\hline wt.\%(P) & 14.0 & $14.1 \pm 0.1$ & 13.4 & $13.4 \pm 0.2$ & 13.0 & $13.3 \pm 0.3$ & 12.1 & $12.2 \pm 0.1$ \\
\hline wt.\%(Ca) & 32.5 & $31.9 \pm 0.1$ & 32.1 & $33.7 \pm 0.3$ & 31.9 & $31.2 \pm 0.6$ & 31.3 & $31.6 \pm 0.3$ \\
\hline wt. $\%(\mathrm{Nd})$ & 13.0 & $13.3 \pm 0.4$ & 10.9 & $10.5 \pm 0.5$ & 9.6 & $10.0 \pm 0.5$ & 6.3 & $6.5 \pm 0.3$ \\
\hline wt.\%(Th) & --- & --- & 3.1 & $3.0 \pm 0.2$ & 5.1 & $5.2 \pm 0.5$ & 10.1 & $10.6 \pm 0.4$ \\
\hline$x_{\mathrm{Nd}}$ & & $0.03 \pm 0.01$ & & $0.18 \pm 0.01$ & & $0.22 \pm 0.01$ & & $0.53 \pm 0.02$ \\
\hline$x_{\mathrm{Th}}$ & & 0 & & $0.15 \pm 0.01$ & & $0.26 \pm 0.03$ & & $0.51 \pm 0.02$ \\
\hline$x_{\mathrm{PO}_{4}}$ & & $0.00 \pm 0.01$ & & $0.12 \pm 0.01$ & & $0.14 \pm 0.01$ & & $0.49 \pm 0.01$ \\
\hline$x_{\mathrm{SiO}_{4}}$ & & $0.02 \pm 0.01$ & & $0.15 \pm 0.01$ & & $0.22 \pm 0.01$ & & $0.55 \pm 0.01$ \\
\hline $\bar{x}$ & & $0.01 \pm 0.01$ & & $0.15 \pm 0.01$ & & $0.21 \pm 0.01$ & & $0.52 \pm 0.01$ \\
\hline
\end{tabular}

\begin{tabular}{|c|c|c|c|c|c|c|}
\hline & \multicolumn{2}{|c|}{$x=0.75$} & \multicolumn{2}{|c|}{$x=0.85$} & \multicolumn{2}{|c|}{$x=1$} \\
\hline & Calc. & Exp. & Calc. & Exp. & Calc. & Exp. \\
\hline wt. $\%(\mathrm{O}) *$ & 32.7 & $33.2 \pm 0.4$ & 32.5 & $32.6 \pm 0.2$ & 32.1 & $32.4 \pm 0.2$ \\
\hline wt.\%(F) & 3.3 & $2.3 \pm 0.2$ & 3.2 & $2.1 \pm 0.1$ & 3.8 & $1.8 \pm 0.1$ \\
\hline wt. \%(Si) & 4.2 & $4.0 \pm 0.1$ & 4.4 & $4.3 \pm 0.1$ & 4.7 & $4.8 \pm 0.2$ \\
\hline wt.\%(P) & 11.2 & $11.4 \pm 0.2$ & 10.9 & $11.0 \pm 0.1$ & 10.4 & $10.3 \pm 0.2$ \\
\hline wt.\%(Ca) & 30.7 & $30.4 \pm 0.4$ & 30.5 & $31.8 \pm 0.2$ & 30.2 & $31.2 \pm 0.4$ \\
\hline wt. $\%(\mathrm{Nd})$ & 3.1 & $3.4 \pm 0.2$ & 1.8 & $1.8 \pm 0.1$ & --- & --- \\
\hline wt. \%(Th) & 14.8 & $15.3 \pm 0.4$ & 16.7 & $16.4 \pm 0.4$ & 19.4 & $19.4 \pm 0.7$ \\
\hline$x_{\mathrm{Nd}}$ & & $0.72 \pm 0.04$ & & $0.85 \pm 0.05$ & & 1 \\
\hline$x_{\mathrm{Th}}$ & & $0.78 \pm 0.02$ & & $0.84 \pm 0.02$ & & $1.01 \pm 0.04$ \\
\hline$x_{\mathrm{PO}_{4}}$ & & $0.65 \pm 0.01$ & & $0.79 \pm 0.01$ & & $0.99 \pm 0.02$ \\
\hline$x_{\mathrm{SiO}_{4}}$ & & $0.70 \pm 0.02$ & & $0.84 \pm 0.02$ & & $1.05 \pm 0.05$ \\
\hline $\bar{x}$ & & $0.71 \pm 0.02$ & & $0.83 \pm 0.02$ & & $1.01 \pm 0.03$ \\
\hline
\end{tabular}

* obtained by difference 
Table 6. Results of EPMA analysis for $\mathrm{Ca}_{9} \mathrm{Nd}_{1-x} \mathrm{Th}_{x}\left(\mathrm{PO}_{4}\right)_{5}\left(\mathrm{SiO}_{4}\right)_{1} \mathrm{~F}_{2-x} \mathrm{O}_{x}$ samples $(0.25 \leq x \leq 1)$.

\begin{tabular}{|c|c|c|c|c|c|c|c|c|c|c|}
\hline & \multicolumn{2}{|r|}{$x=0.25$} & \multicolumn{2}{|r|}{$x=0.5$} & \multicolumn{2}{|r|}{$x=0.66$} & \multicolumn{2}{|c|}{$x=0.75$} & \multicolumn{2}{|r|}{$x=1$} \\
\hline & Calc. & Exp. & Calc. & Exp. & Calc. & Exp. & Calc. & Exp. & Calc. & Exp. \\
\hline wt. $\%(\mathrm{O}) *$ & 34.3 & $34.7 \pm 0.4$ & 34.0 & $34.4 \pm 0.2$ & 33.8 & $33.4 \pm 0.2$ & 33.8 & $34.4 \pm 0.3$ & 33.5 & $36.0 \pm 0.2$ \\
\hline wt. \%(F) & 2.9 & $2.7 \pm 0.2$ & 2.5 & $2.3 \pm 0.1$ & 2.2 & $2.8 \pm 0.1$ & 2.0 & $2.4 \pm 0.2$ & 1.6 & $2.8 \pm 0.1$ \\
\hline wt. \%(Si) & 2.5 & $2.4 \pm 0.1$ & 2.4 & $2.5 \pm 0.1$ & 2.4 & $2.4 \pm 0.1$ & 2.4 & $2.4 \pm 0.2$ & 2.3 & $1.7 \pm 0.2$ \\
\hline wt. \%(P) & 13.7 & $13.9 \pm 0.4$ & 13.4 & $13.6 \pm 0.2$ & 13.3 & $13.6 \pm 0.2$ & 13.2 & $13.8 \pm 0.3$ & 13.0 & $15.6 \pm 0.3$ \\
\hline wt. \%(Ca) & 31.9 & $31.9 \pm 0.4$ & 31.3 & $31.2 \pm 0.4$ & 30.9 & $33.4 \pm 0.3$ & 30.7 & $32.2 \pm 0.4$ & 30.2 & $35.0 \pm 0.5$ \\
\hline wt. $\%(\mathrm{Nd})$ & 9.6 & $9.5 \pm 0.5$ & 6.3 & $6.5 \pm 0.3$ & 4.2 & $4.2 \pm 0.3$ & 3.1 & $3.5 \pm 0.2$ & --- & -- \\
\hline wt. \%(Th) & 5.1 & $4.9 \pm 0.4$ & 10.1 & $9.5 \pm 0.5$ & 13.1 & $10.3 \pm 1.0$ & 14.8 & $11.3 \pm 0.6$ & 19.4 & $8.9 \pm 0.9$ \\
\hline \multicolumn{11}{|l|}{ Mole ratio } \\
\hline $\mathrm{Si} / \mathrm{P}$ & 0.200 & $0.191 \pm 0.015$ & 0.200 & $0.200 \pm 0.012$ & 0.200 & $0.191 \pm 0.014$ & 0.200 & $0.192 \pm 0.019$ & 0.200 & $0.119 \pm 0.013$ \\
\hline $\mathrm{Nd} / \mathrm{Ca}$ & 0.083 & $0.083 \pm 0.006$ & 0.056 & $0.058 \pm 0.003$ & 0.038 & $0.035 \pm 0.003$ & 0.028 & $0.030 \pm 0.002$ & --- & -- \\
\hline $\mathrm{Th} / \mathrm{Ca}$ & 0.028 & $0.026 \pm 0.002$ & 0.056 & $0.053 \pm 0.003$ & 0.073 & $0.053 \pm 0.006$ & 0.083 & $0.061 \pm 0.004$ & 0.111 & $0.044 \pm 0.005$ \\
\hline $\begin{array}{c}(\mathrm{Si}+\mathrm{P}) / \\
(\mathrm{Ca}+\mathrm{Nd}+\mathrm{Th})\end{array}$ & 0.600 & $0.606 \pm 0.008$ & 0.600 & $0.610 \pm 0.007$ & 0.600 & $0.575 \pm 0.006$ & 0.600 & $0.605 \pm 0.012$ & 0.600 & $0.617 \pm 0.015$ \\
\hline$x_{\mathrm{Nd}}$ & & $.25 \pm 0.01$ & & $.48 \pm 0.02$ & & $.68 \pm 0.02$ & & $73 \pm 0.04$ & & 1 \\
\hline$x_{\mathrm{Th}}$ & & $.24 \pm 0.02$ & & $.47 \pm 0.02$ & & $.49 \pm 0.05$ & & $55 \pm 0.03$ & & $41 \pm 0.04$ \\
\hline$x_{\mathrm{F}}$ & & $.41 \pm 0.12$ & & $.60 \pm 0.06$ & & $.38 \pm 0.06$ & & $55 \pm 0.12$ & & $39 \pm 0.06$ \\
\hline$x_{\mathrm{O}}$ & & $.23 \pm 0.01$ & & $.37 \pm 0.01$ & & $.75 \pm 0.01$ & & $38 \pm 0.01$ & & $00 \pm 0.01$ \\
\hline \multicolumn{11}{|l|}{$\begin{array}{l}\text { Proposed } \\
\text { formulae }\end{array}$} \\
\hline $\mathrm{Ca}$ & & $3.97 \pm 0.11$ & & $.94 \pm 0.11$ & & $.19 \pm 0.08$ & & $13 \pm 0.11$ & & $46 \pm 0.14$ \\
\hline $\mathrm{Nd}$ & & $.75 \pm 0.04$ & & $.52 \pm 0.02$ & & $.32 \pm 0.02$ & & $27 \pm 0.02$ & & --- \\
\hline Th & & $.24 \pm 0.02$ & & $.47 \pm 0.02$ & & $.49 \pm 0.05$ & & $55 \pm 0.03$ & & $41 \pm 0.04$ \\
\hline $\mathrm{PO}_{4}$ & & $.07 \pm 0.15$ & & $.05 \pm 0.07$ & & $.83 \pm 0.07$ & & $06 \pm 0.11$ & & $45 \pm 0.10$ \\
\hline $\mathrm{SiO}_{4}$ & & $.97 \pm 0.04$ & & $.01 \pm 0.04$ & & $.92 \pm 0.04$ & & $97 \pm 0.08$ & & $65 \pm 0.08$ \\
\hline $\mathrm{F}$ & & $.59 \pm 0.12$ & & $.40 \pm 0.06$ & & $.62 \pm 0.06$ & & $45 \pm 0.12$ & & $61 \pm 0.06$ \\
\hline $\mathrm{O}$ & & $.23 \pm 0.01$ & & $.37 \pm 0.01$ & & $.75 \pm 0.01$ & & $38 \pm 0.01$ & & $00 \pm 0.01$ \\
\hline
\end{tabular}

* obtained by difference 
Table 7. Refined unit cell parameters and volume of $\mathrm{Ca}_{9} \mathrm{Nd}_{1-x} \mathrm{Th}_{x}\left(\mathrm{PO}_{4}\right)_{5}\left(\mathrm{SiO}_{4}\right)_{1} \mathrm{~F}_{2-x} \mathrm{O}_{x}$ britholites $(0 \leq x \leq 1)$.

\begin{tabular}{ccccc}
\hline$x_{\text {expected }}$ & $a(\AA)$ & $c(\AA)$ & $\mathrm{V}\left(\AA^{3}\right)$ & $\mathrm{F}_{20}$ \\
\hline 0 & $9.401(2)$ & $6.902(1)$ & $528.2(4)$ & $195(0.0033 ; 31)$ \\
0.25 & $9.401(2)$ & $6.902(1)$ & $528.3(4)$ & $174(0.0037 ; 31)$ \\
0.50 & $9.401(2)$ & $6.900(1)$ & $528.1(4)$ & $174(0.0037 ; 31)$ \\
0.66 & $9.403(2)$ & $6.903(1)$ & $528.5(4)$ & $258(0.0025 ; 31)$ \\
0.75 & $9.397(2)$ & $6.895(1)$ & $527.3(4)$ & $174(0.0037 ; 31)$ \\
1.00 & $9.392(2)$ & $6.893(1)$ & $526.5(4)$ & $111(0.0045 ; 40)$ \\
\hline
\end{tabular}




\section{Figure captions}

Figure 1. Micrographies in BSE mode of (Nd,Th)-britholites (with $x=0.5$ ): manual grinding (a), mechanical grinding at $30 \mathrm{~Hz}(15 \mathrm{~min}$.) (b). Black zones are pores in the samples.

Figure 2. TGA and DTA experiments performed on reagents mechanically grounded for the synthesis of $(\mathrm{Nd}, \mathrm{Th})$ - britholites $(x=0.5)$.

Figure 3. Variation of the XRD patterns of $(\mathrm{Nd}, \mathrm{Th})$-britholites $(x=0.5)$ versus the heating temperature. Main diffraction lines of $\mathrm{ThO}_{2}(*), \mathrm{Nd}_{2} \mathrm{O}_{3}(\#)$ and $\mathrm{Ca}_{2} \mathrm{P}_{2} \mathrm{O}_{7}$ (o).

Figure 4. Variations of refined unit cell parameters $a$ (a) and $c$ (b) for the apatite or britholite major phase versus the heat temperature $(t=6$ hours $)$. The hatched zones correspond to the possible variations of the parameters of each phases reported in the literature or in this study.

Figure 5. Variations of the ratio between the experimental weight percent (deduced from EPMA experiments) over that expected for each elements of ( $\mathrm{Nd}, \mathrm{Th})$-britholite (with $x=0.5$ ): $\mathrm{F}, \mathrm{P}, \mathrm{Ca}(\mathrm{a})$ and $\mathrm{Si}, \mathrm{Nd}$, Th (b) versus the heating temperature $(\mathrm{t}=6$ hours).

Figure 6. XRD patterns of $\mathrm{Ca}_{9} \mathrm{Nd}_{1-x} \mathrm{Th}_{x}\left(\mathrm{PO}_{4}\right)_{5-x}\left(\mathrm{SiO}_{4}\right)_{1+x} \mathrm{~F}_{2}$ britholites for several $x$ values.

Figure 7. $\mu$-Raman (left) and infra-red (right) spectra of Nd-britholite (a) and $(\mathrm{Nd}, \mathrm{Th})$-britholite $(x=0.5)(\mathrm{b})$.

Figure 8. Variations of refined unit cell parameters $a$ and $c$ (a) and volume (b) of $\mathrm{Ca}_{9} \mathrm{Nd}_{1-x} \mathrm{Th}_{x}\left(\mathrm{PO}_{4}\right)_{5-x}\left(\mathrm{SiO}_{4}\right)_{1+x} \mathrm{~F}_{2}$ britholites versus the average substitution rate $\bar{x}$.

Figure 9. SEM observations of $\mathrm{Ca}_{9} \mathrm{Nd}_{1-x} \mathrm{Th}_{x}\left(\mathrm{PO}_{4}\right)_{5-x}\left(\mathrm{SiO}_{4}\right)_{1+x} \mathrm{~F}_{2}$ britholites: $x=0$ (a), $x=0.25(\mathrm{~b}), x=0.5(\mathrm{c}), x=0.75(\mathrm{~d})$ and $x=1(\mathrm{e}-\mathrm{f})$.

Figure 10. Variations of the ratio between the elementary experimental weight percent (deduced from EPMA experiments) over that expected for $\mathrm{Ca}_{9} \mathrm{Nd}_{1-x} \mathrm{Th}_{x}\left(\mathrm{PO}_{4}\right)_{5}\left(\mathrm{SiO}_{4}\right) \mathrm{F}_{2-x} \mathrm{O}_{x}$ britholite versus the expected substitution rate $x$.

Figure 11. Variations of refined unit cell parameters $a$ and $c$ (a) and volume (b) of $\mathrm{Ca}_{9} \mathrm{Nd}_{1-x} \mathrm{Th}_{x}\left(\mathrm{PO}_{4}\right)_{5}\left(\mathrm{SiO}_{4}\right)_{1} \mathrm{~F}_{2-x} \mathrm{O}_{x}$ britholites versus the expected substitution rate.

Figure 12. Variation of the experimental incorporation rate versus expected rate through the $\left(\mathrm{Nd}^{3+}, \mathrm{PO}_{4}^{3-}\right) \Leftrightarrow\left(\mathrm{Th}^{4+}, \mathrm{SiO}_{4}{ }^{4-}\right)$ substitution (a) and $\left(\mathrm{Nd}^{3+}, \mathrm{F}\right) \Leftrightarrow\left(\mathrm{Th}^{4+}, \mathrm{O}^{2-}\right)$ substitution (b). 


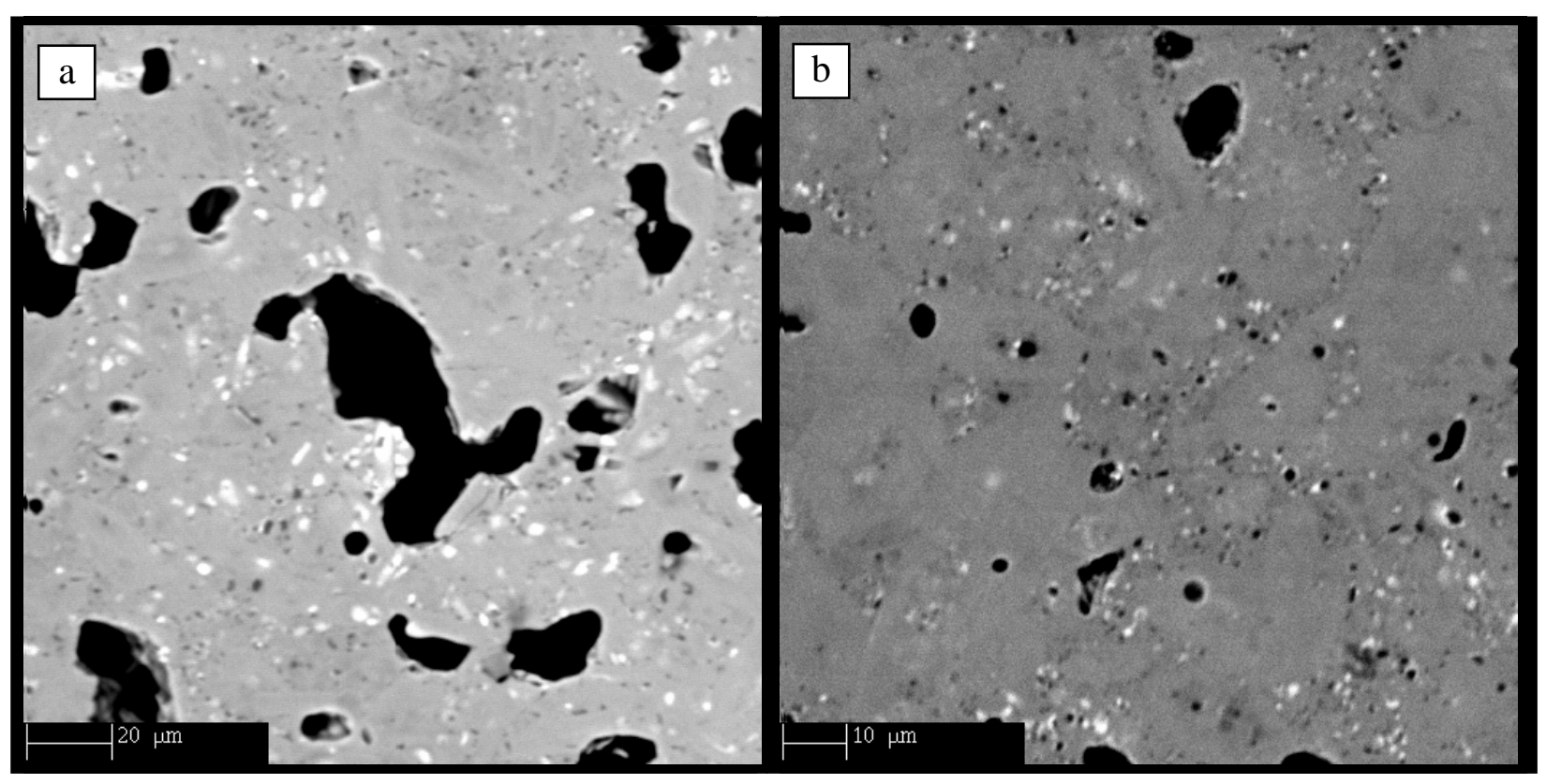

Figure 1. 


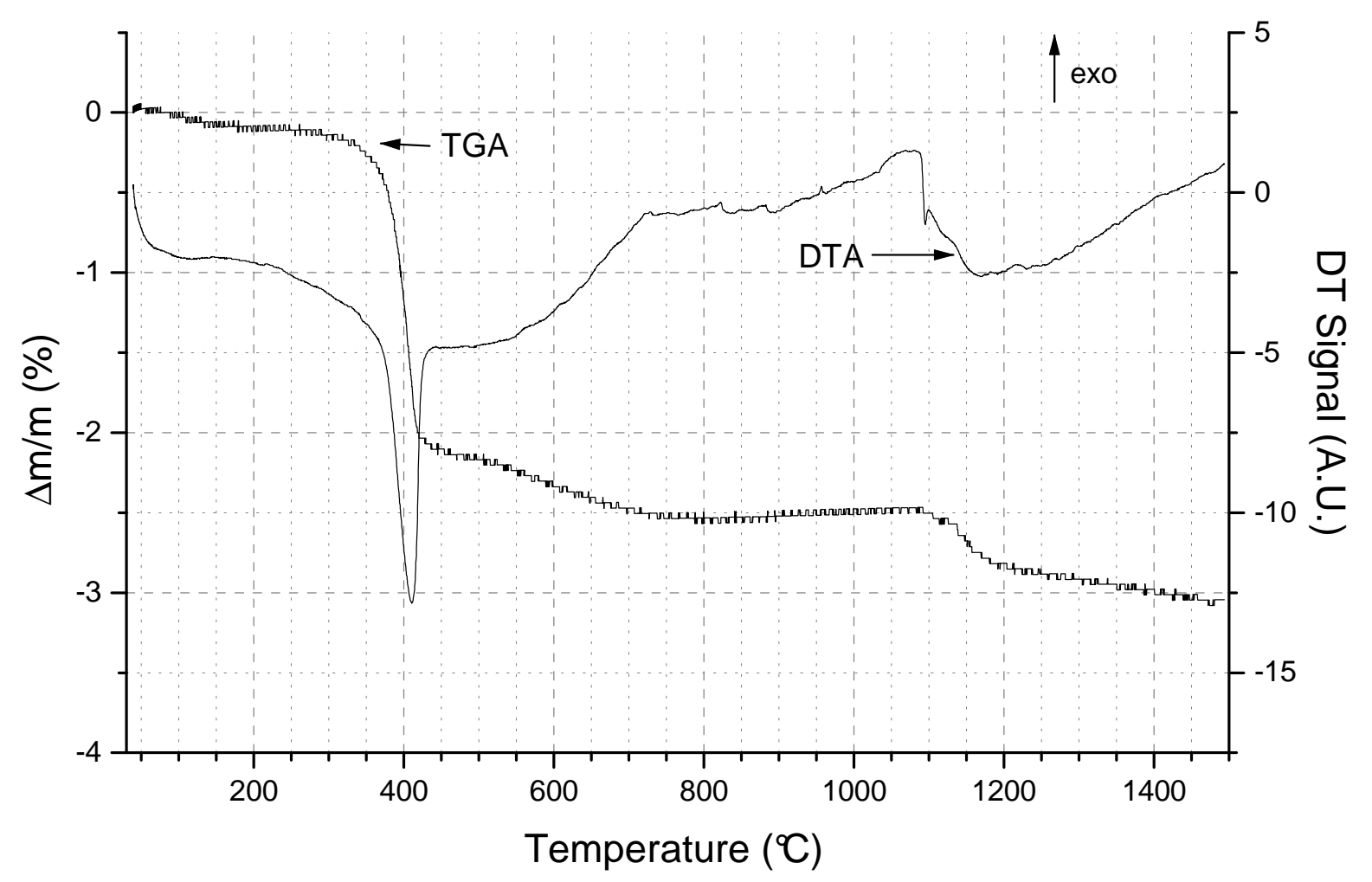

Figure 2. 


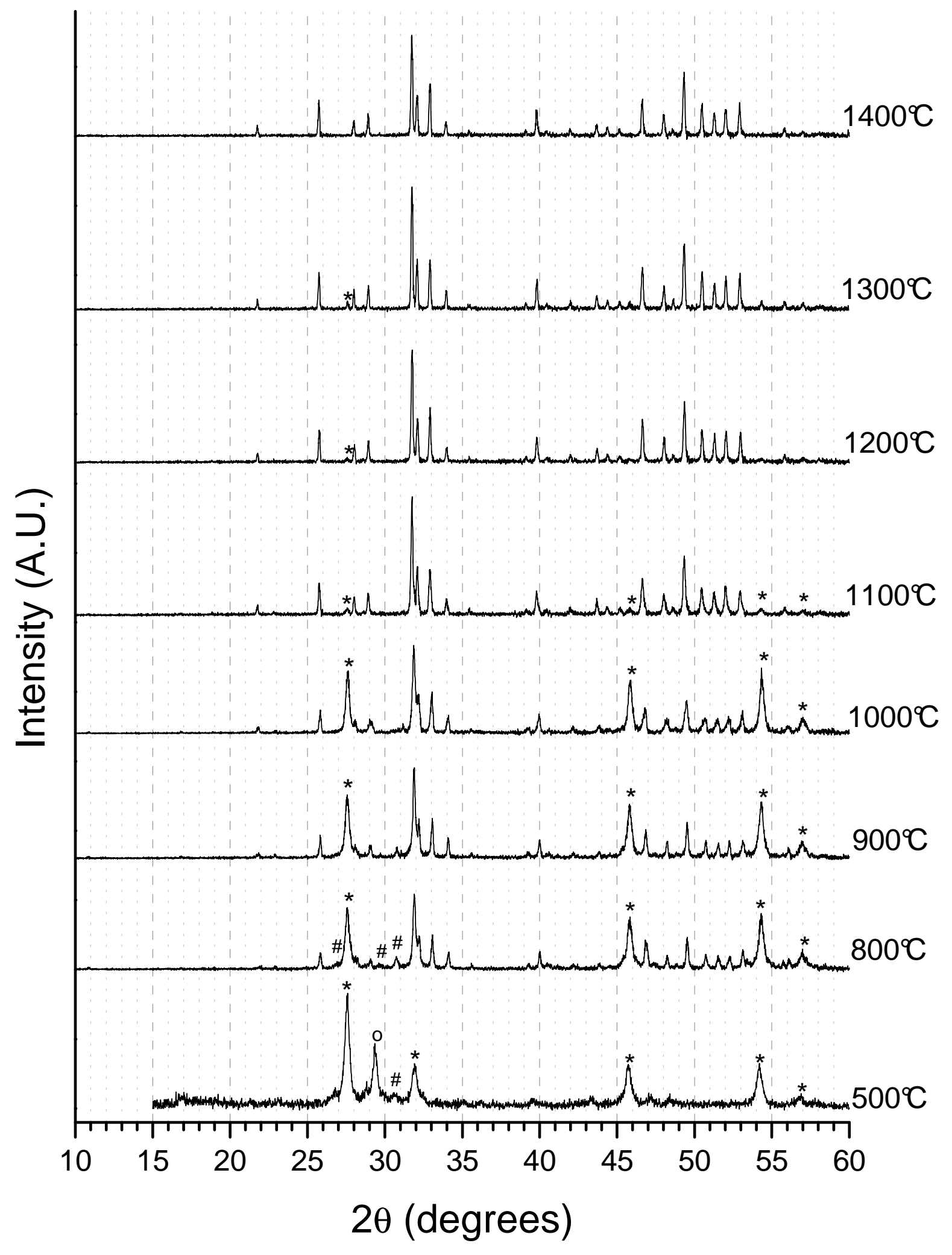

Figure 3. 
$\mathrm{a}$

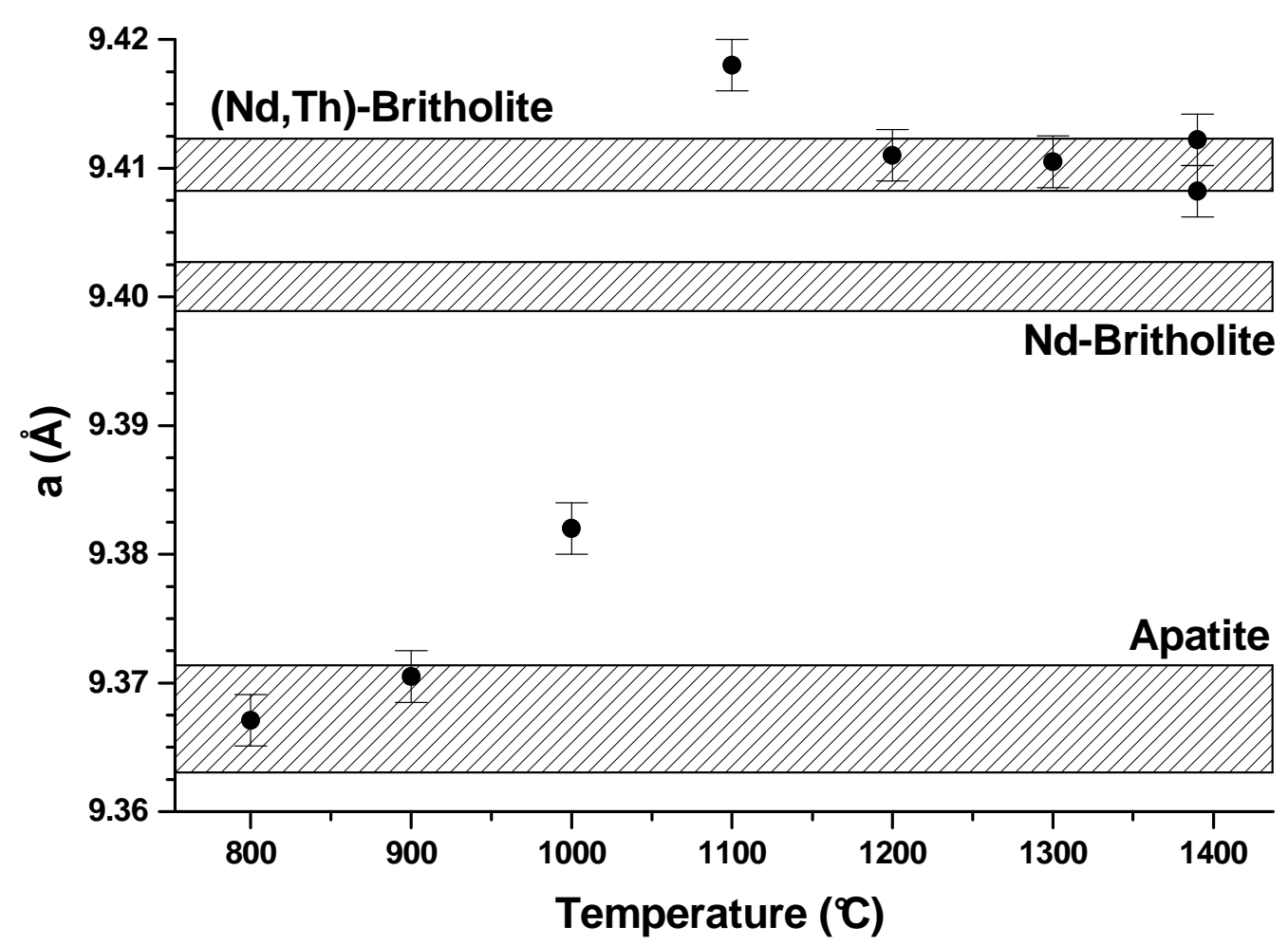

$\mathrm{b}$

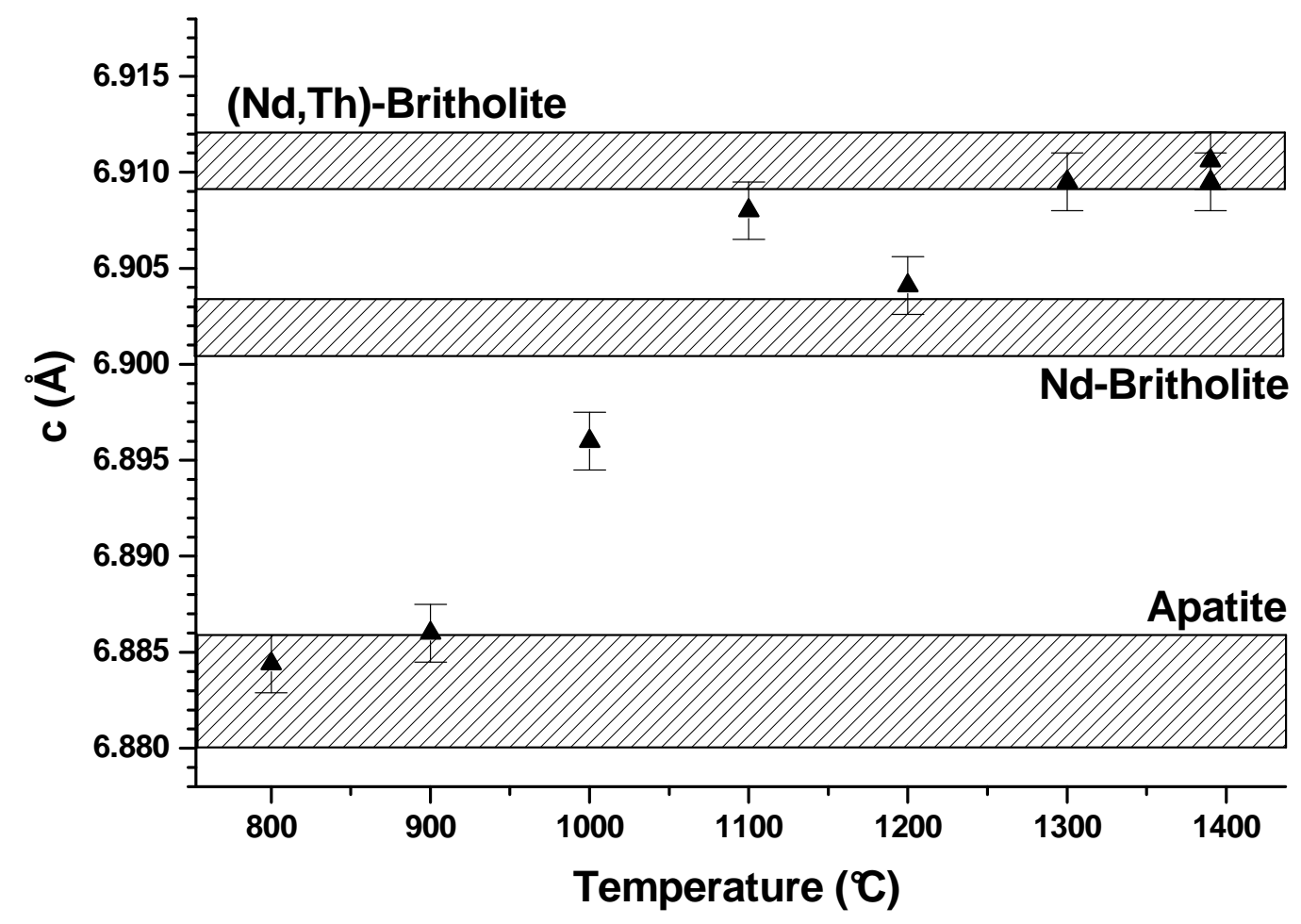

Figure 4. 


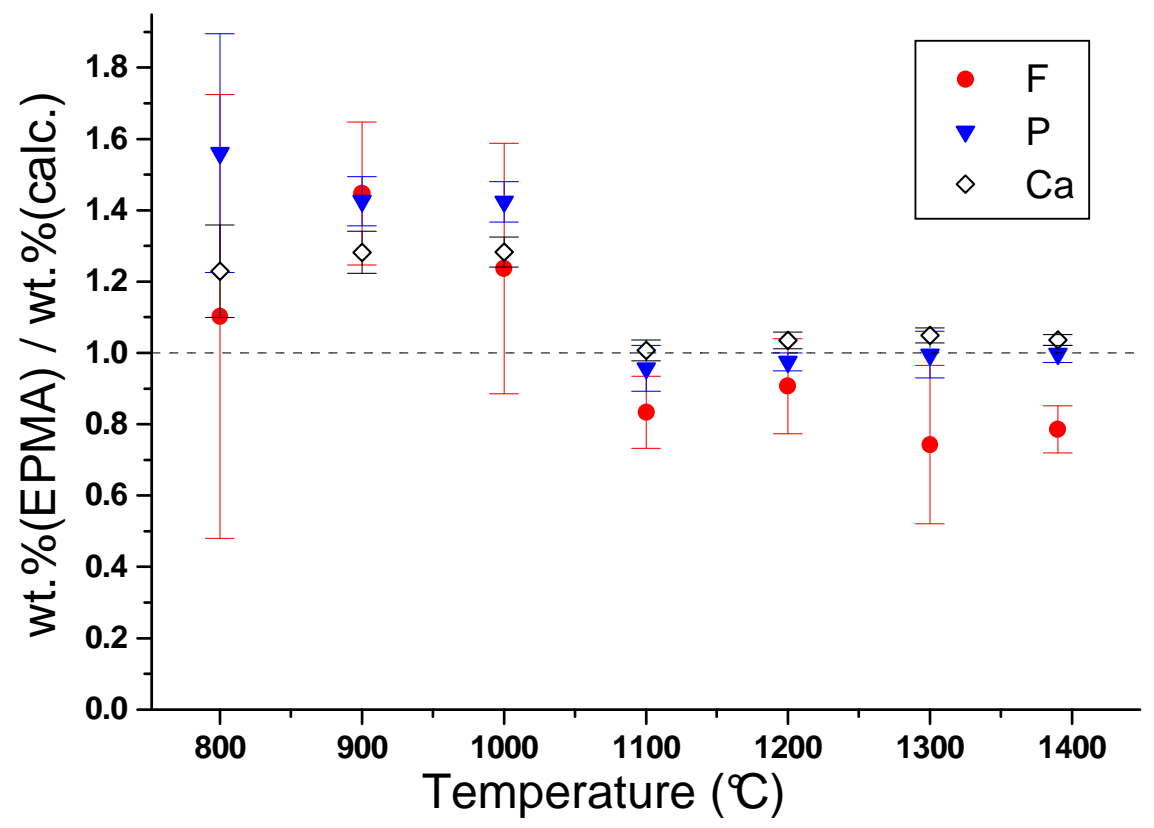

$\mathrm{b}$

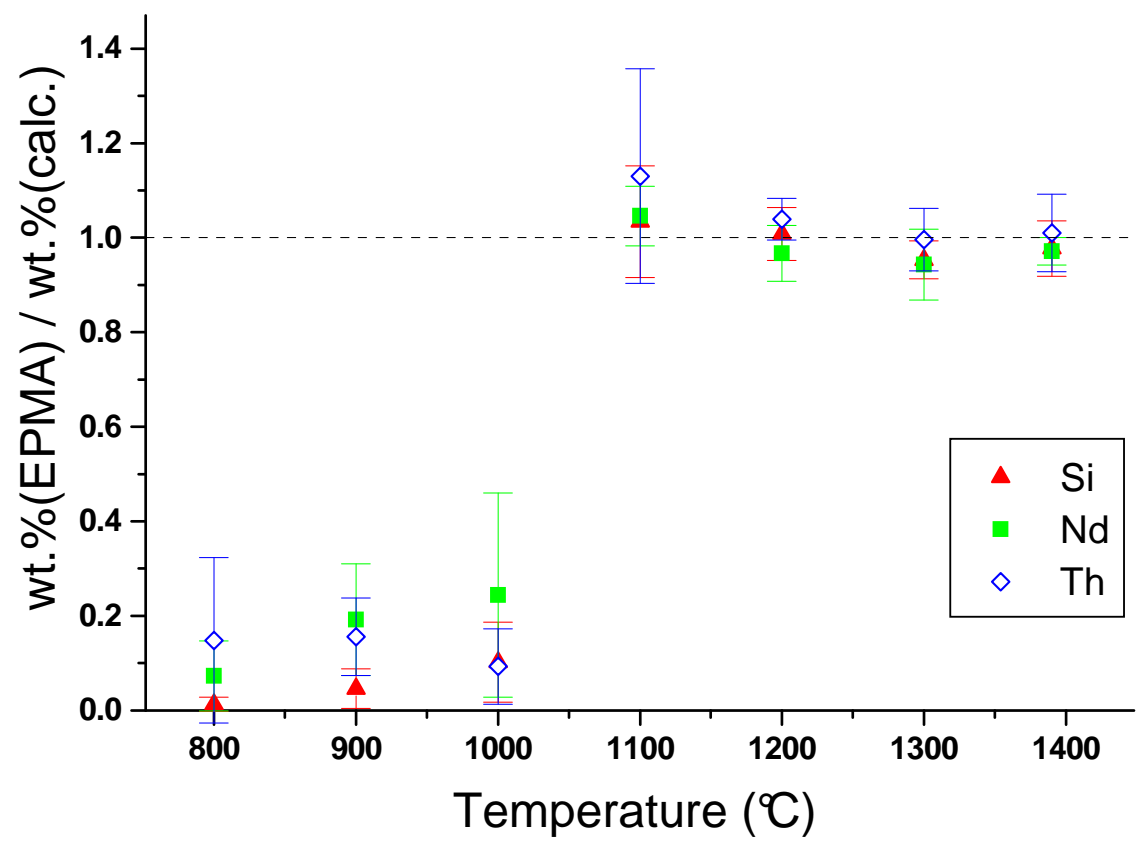

Figure 5. 


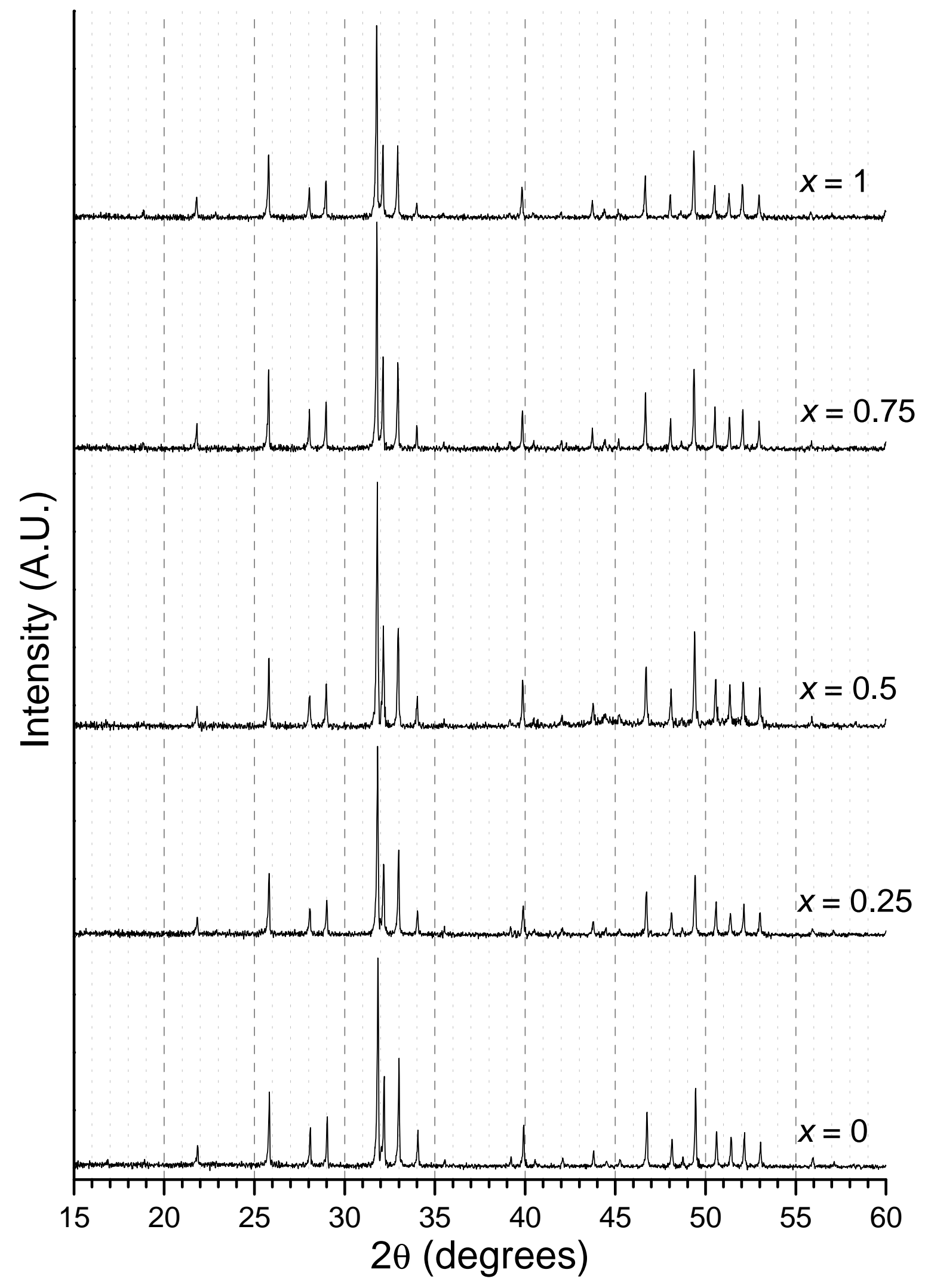

Figure 6. 


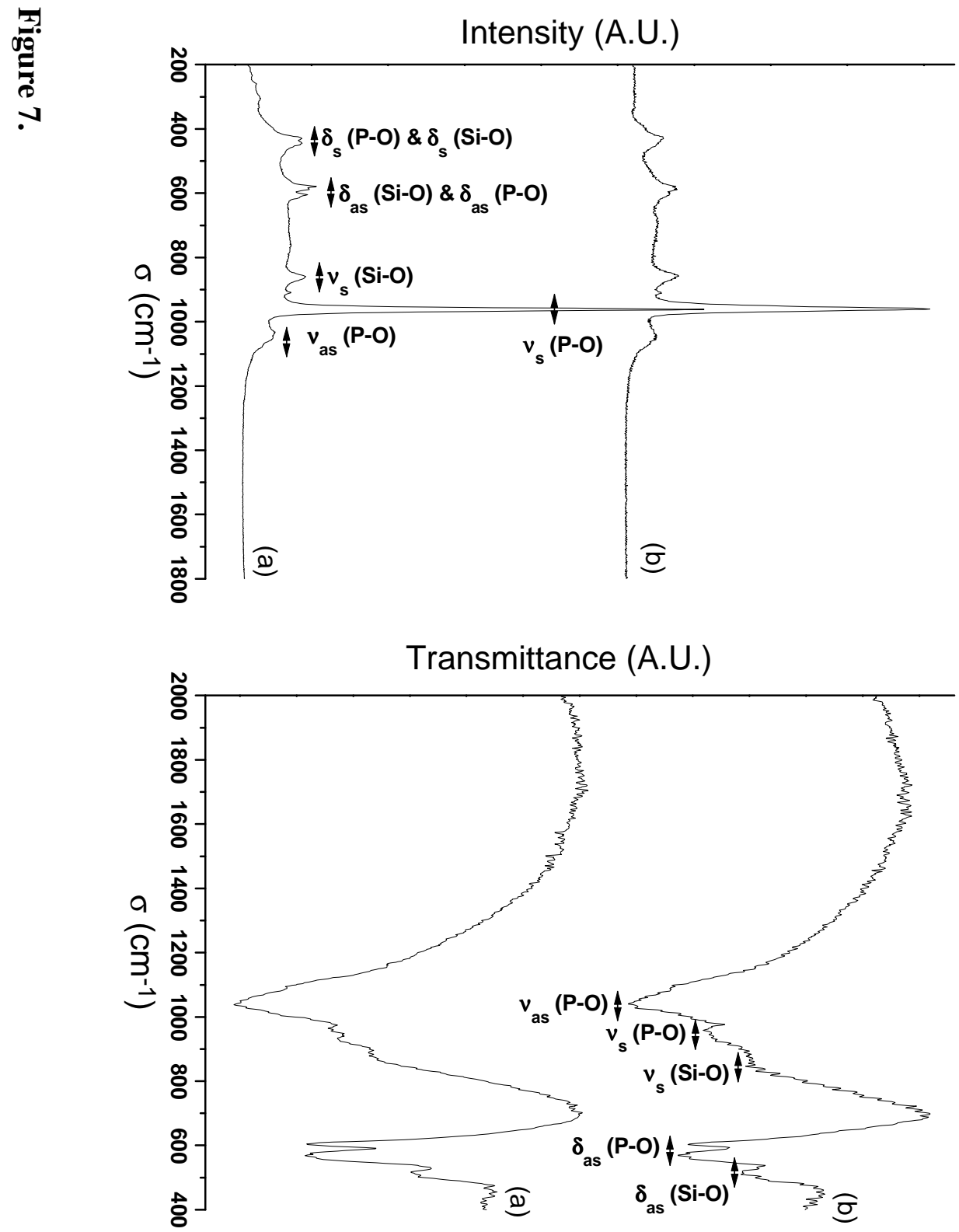


$\mathrm{a}$

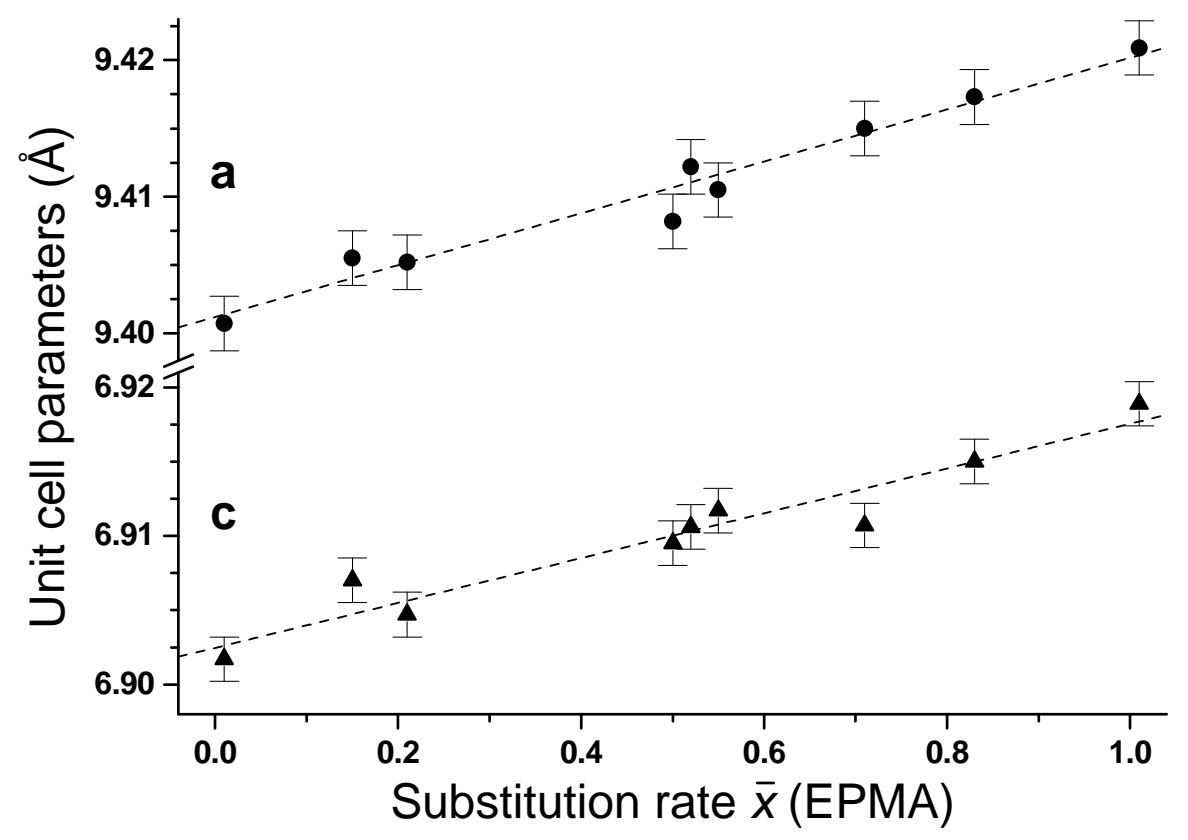

$\mathrm{b}$

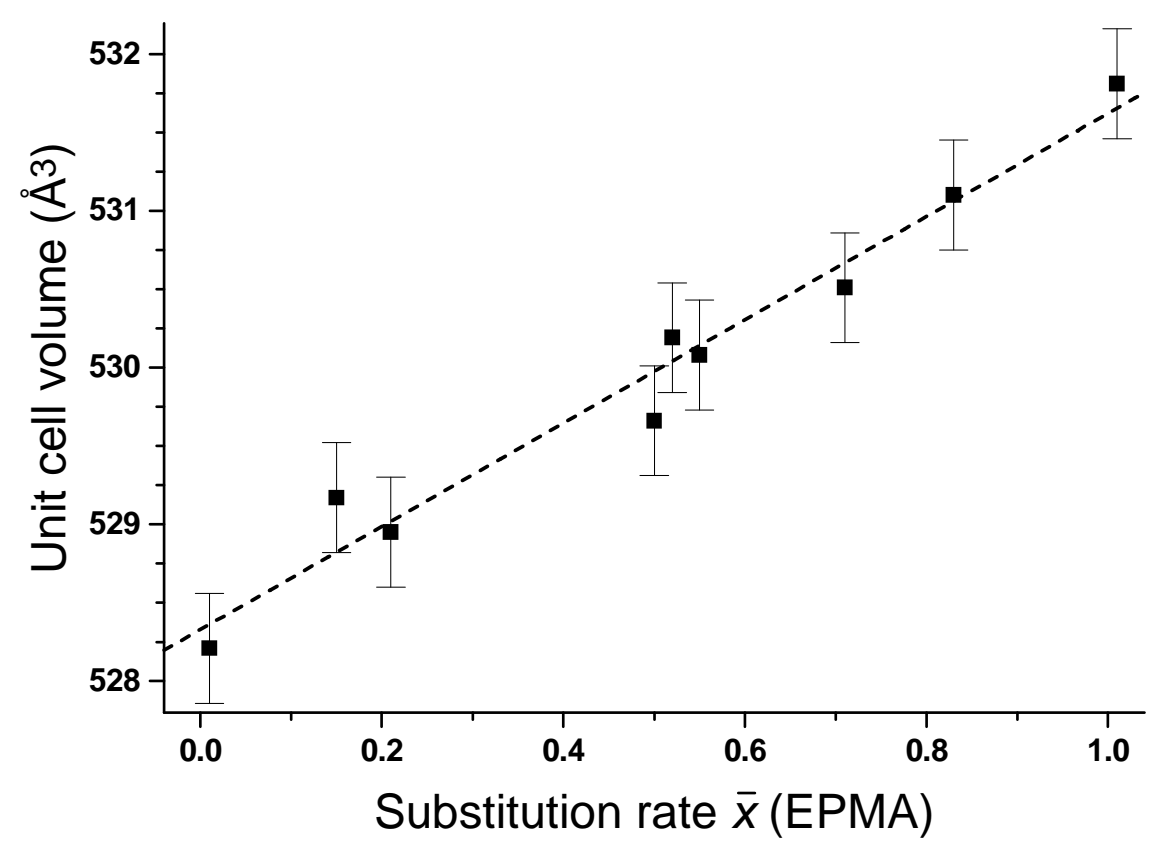

Figure 8. 


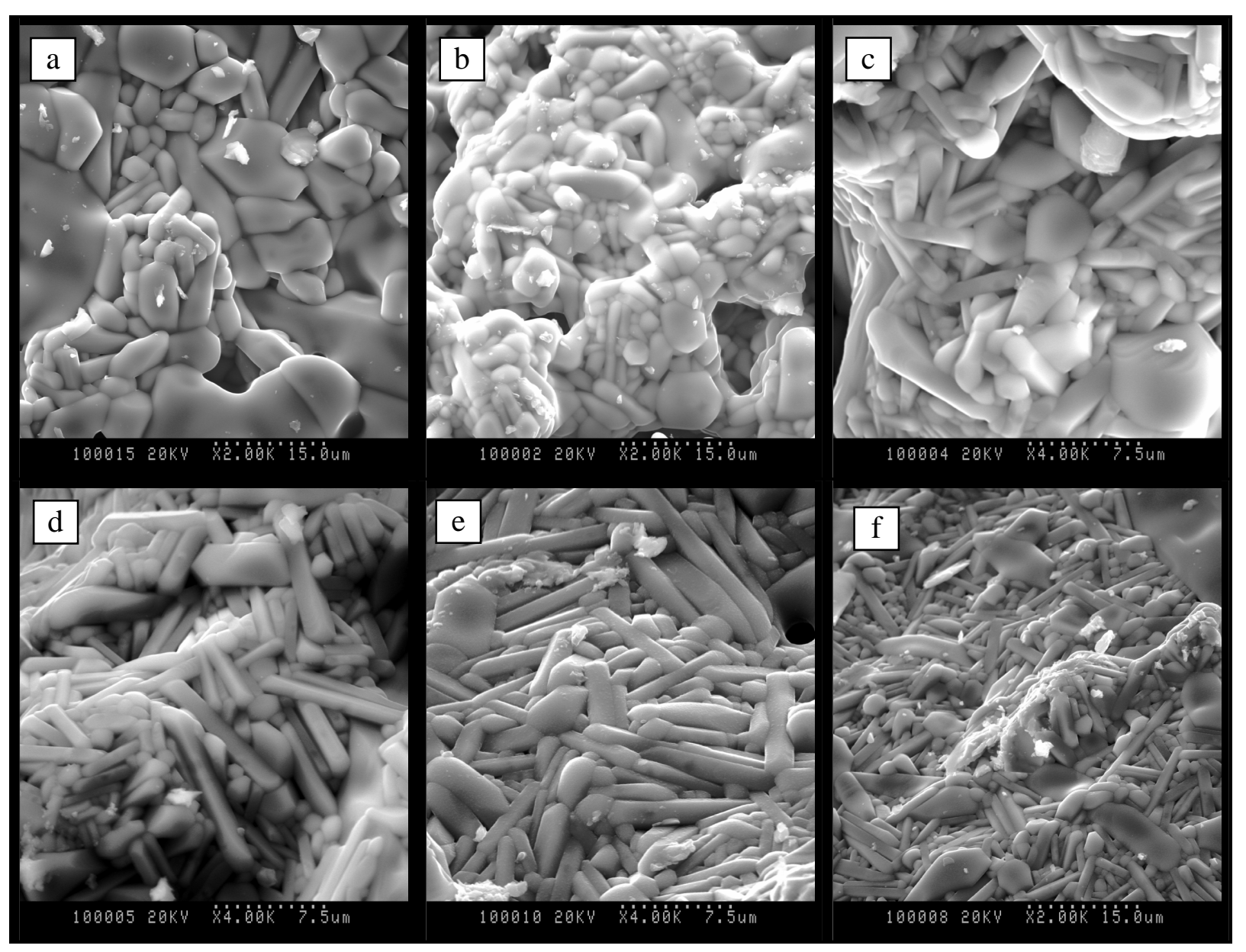

Figure 9. 


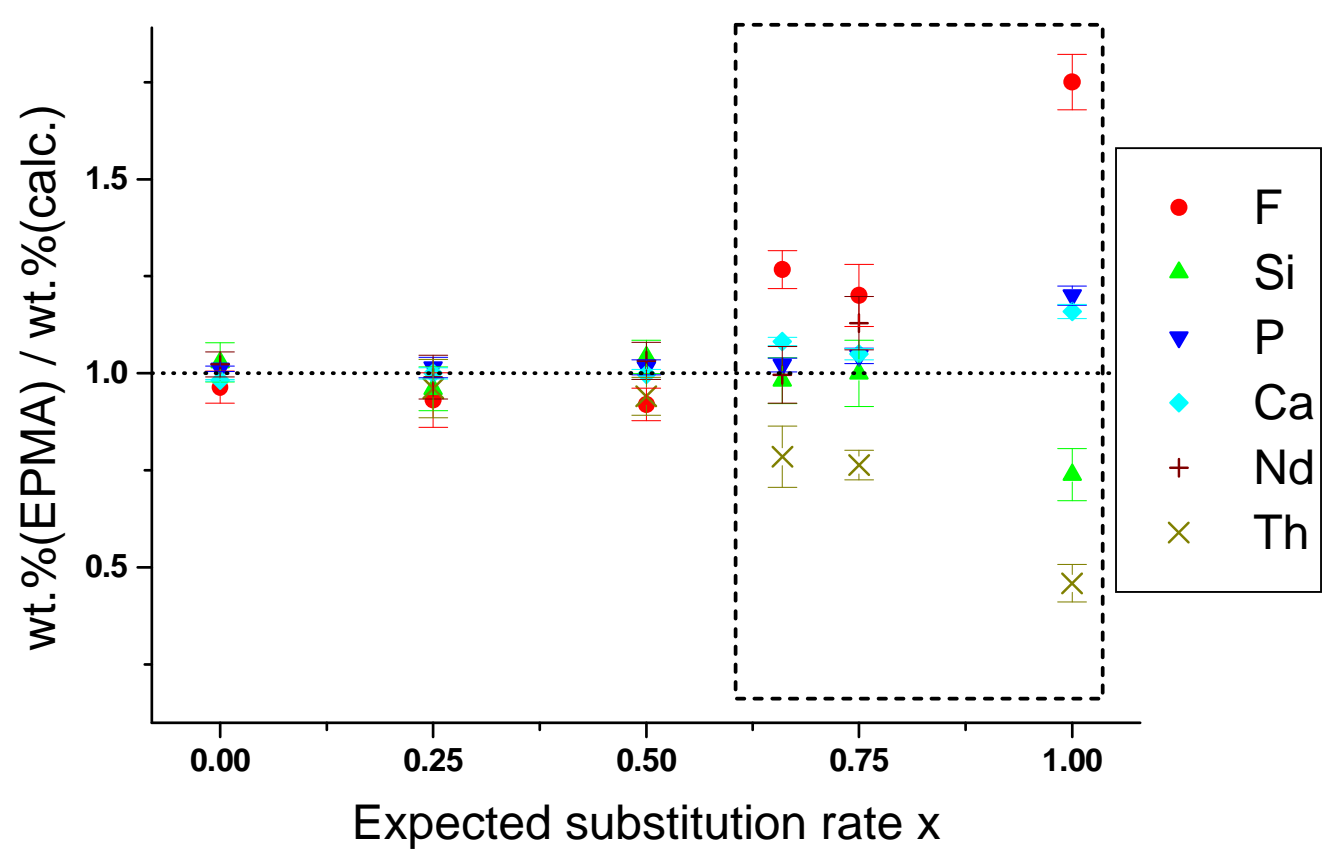

Figure 10. 
$\mathrm{a}$

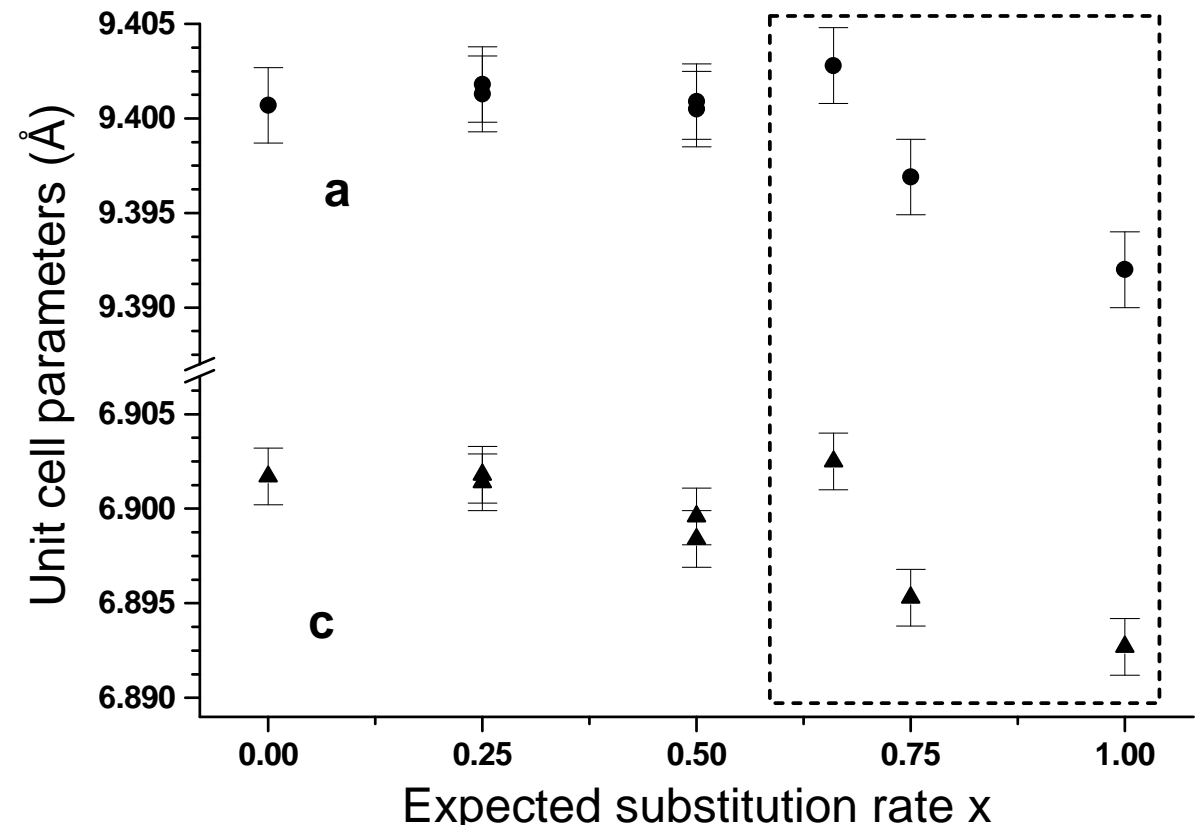

$\mathrm{b}$

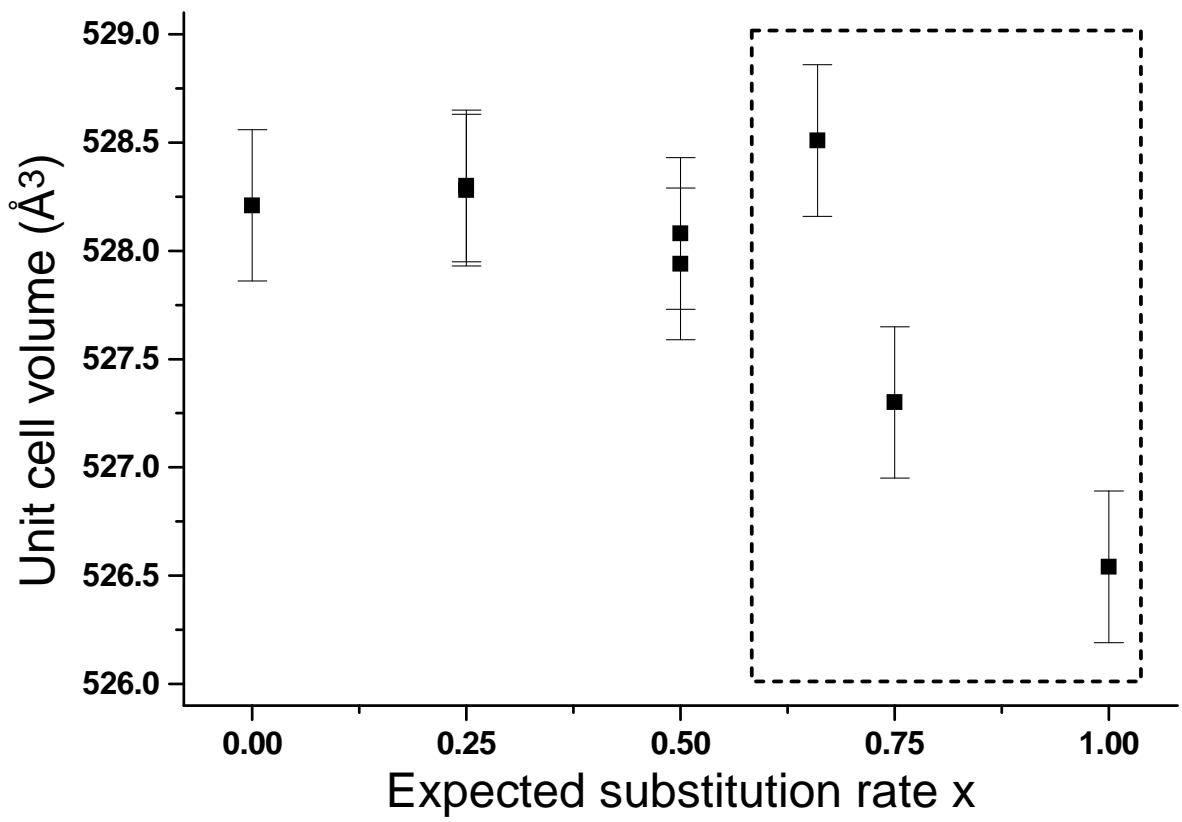

Figure 11. 


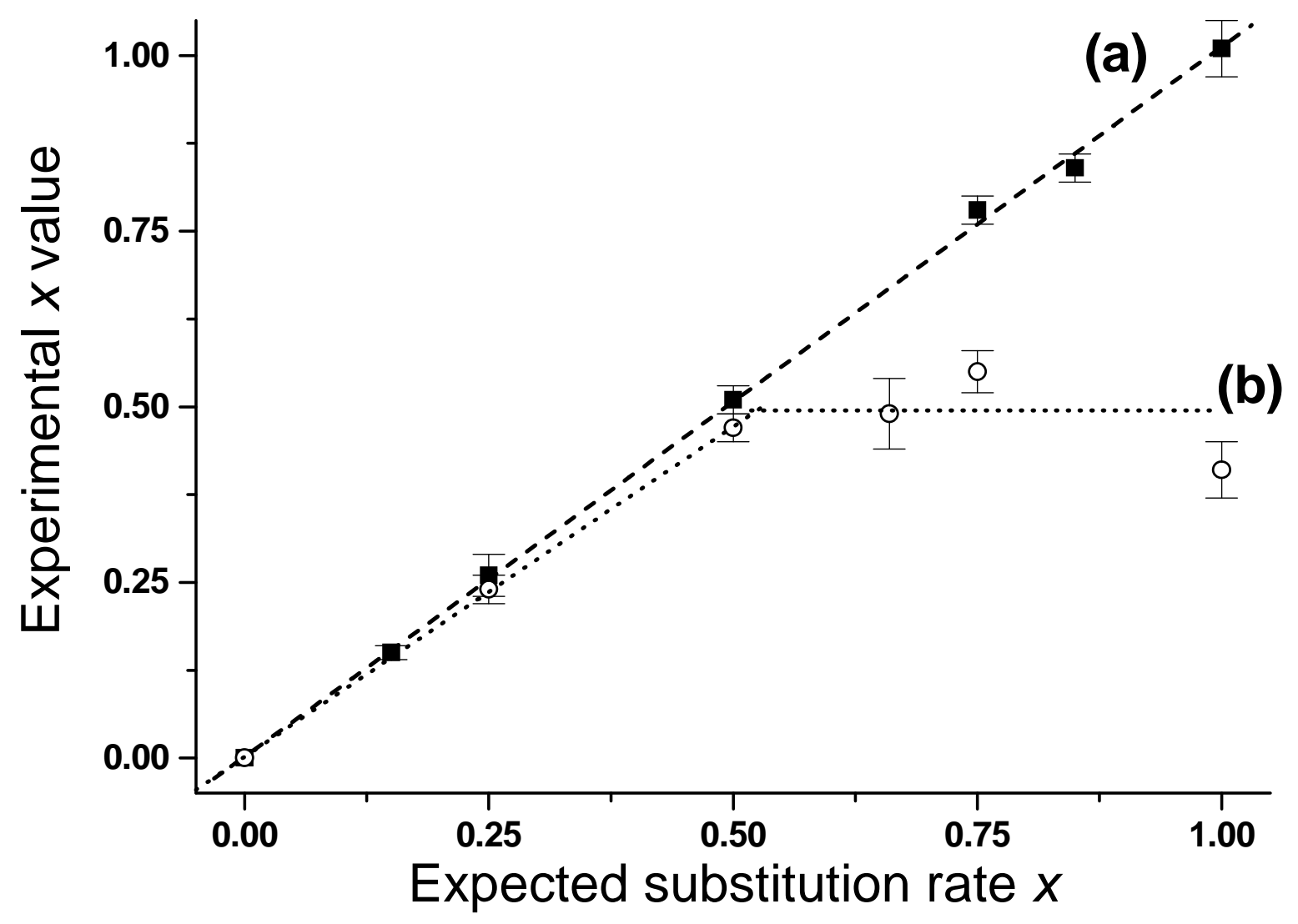

Figure 12. 